v.13, n.5

Vitória-ES, Sep.-Oct. 2016

p. $51-84 \quad$ ISSN 1808-2386

http://dx.doi.org/10.15728/bbr.2016.13.5.3

\title{
Investing in Private Equity in Brazil
}

\author{
Antônio Marcos Duarte Junior \\ IBMEC - RJ / University os State of Rio de Janeiro - UERJ \\ Luiz Carlos Barbosa Medeiros ${ }^{\Omega}$ \\ IBMEC - RJ / Assistance and Social Security Foundation of BNDES - FAPES
}

\begin{abstract}
We consider the problem of selecting private equity funds for investment in Brazil. The proposed methodology is based on multi-criteria decision-making. Real data obtained from one of the largest pension funds in Brazil is used to illustrate a practical application of the methodology when selecting investments among eleven private equity funds available in the local financial market. The multi-criteria method TOPSIS is adopted with a total of twenty two criteria to order the investment alternatives. A sensitivity analysis is also presented. The methodology proposed allows a standardized decision-making process, facilitating the process of selecting private equity funds for investment in Brazilian financial markets.
\end{abstract}

Keywords: Investment selection. Multicriteria decision making. Private equity. TOPSIS.

*Author for correspondence:

†. Ph.D. by the Princeton University - USA.

Link: College Ibmec/RJ \& UERJ

Address: Av. Pres. Wilson, 118, $9^{\circ}$ andar, Rio de Janeiro - RJ.

Brazil. Cep. 20030-020.

E-mail: antoniomarcosdj@uerj.br
$\Omega$ Master of Business Administration, College Ibmec / RJ.

Link: College Ibmec/RJ \& FAPES.

Address: Av. República do Chile, 230, $8^{\circ}$ andar, Rio de

Janeiro - RJ. Brazil. Cep. 20031-170.

E-mail: teresa.carneiro@ufes.br 


\section{INTRODUCTION}

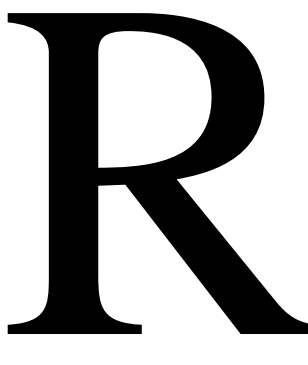

isk Capital can be defined as an investment in companies not listed on exchanges for the subsequent liquidation of positions, with resources returning to investors, providing capital gains (LERNER; FELDA; LEAMON, 2012). Companies considered in this modality of investment usually are in the early stages of development, going through changes in management, corporate restructuring or in search of accelerated growth in the short term (FRASER-SAMPSON, 2010).

Risk capital can be classified as Private Equity (PE) or Venture Capital (VC) (GOMPERS; LERNER, 2004).In the first group (PE) we find investments of greater sum, in more mature companies and operating in well-defined markets, whereas in the second group (VC) we find investment operations in early-stage companies, with high expected returns and that are seeking to establish themselves in a market not yet fully consolidated (CFA INSTITUTE, 2009; KAPLAN; SCHOAR, 2005; KAPLAN; STROMBERG, 2009). The risks and expected returns on VC usually exceed those on PE (CHEN; BAIERL; KAPLAN, 2002; COCHRANE, 2005; GOMPERS; LERNER, 1997\& 1999; PHALIPPOU; GOTTSCHALG, 2009).

Some recent data show the growth and potential of the PE and VC segment in Brazil (KPMG, 2013):

1. At the end of 2012 there were 83 billion (BRL) of committed capital and 28 billion (BRL) still available for investments.

2. The growth of committed capital at the end of 2012 was over $30 \%$ compared to end of 2011.

3. The balance of committed capital by domestic investors surpassed that by foreign investors in 2012.

4. The percentage of committed capital by national pension funds rose from $12 \%$ in 2011 to $16 \%$ in 2012.

5. While total investments in PE and VC in the USA amounted to $0.9 \%$ of GDP in 2012 in Brazil it remains below $0.4 \%$ of GDP. That is, it is reasonable to expect the local market's growth in the long run, with the tendency of bringing its size closer to that of the North American.

Most investors in PE do it indirectly through funds, rather than investing directly in companies (FRASER-SAMPSON, 2010). The motivation for such success lies in that the 
inflow of investments, management and development of resources, and its outflow are recognized as stages that require specific knowledge, experience and dedication, requirements which many investors in PE do not have (METRICK; YASUDA, 2010; PHALIPPOU, 2009).

The management of PE is performed by professional managers representing large institutional investors, such as pension funds (DE ZWART; FRIESER; VAN DIJK, 2012; SWENSEN, 2009). Typically, institutional investors act as limited partners, while professional managers act as general partners. The two partner groups should analyze and select potential investments properly, in face of the high risks present in this type of investment. In other words, partners should provide capital to interested companies only after thoroughly investigating these, in addition to establishing a legal framework that would offer them security in order to receive back in the future invested resources and earnings (BYGRAVE; TIMMONS, 1992).

In this study, we concentrate on PE investments in Brazil. The most common PE investment vehicle in Brazil is the Fundo de Investimento em Participações (FIP), with the main investors in the industry being pension funds, asset managers, institutional investors, family offices and foreign investors (ABDI, 2011). According to Instruction CVM 391 (COMISSÃO DE VALORES MOBILIÁRIOS, 2014), a FIP is constituted in the form of a closed condominium, as a pooling of resources for the purchase of shares, debentures, subscription bonds or other bonds, and securities that are convertible or exchangeable into shares issued by companies, with participation in the decision-making process of the invested company, and with effective influence in the definition of strategic policy and management, notably by appointing members to its Board of Directors. Commonly, the PE fund managers receive a percentage of the committed capital and/or equity of the fund as an administration or performance fee, in case of surpassing benchmarks.

Investors should use methodologies to assist them in a structured way when choosing the best investments for their investment portfolios (BANA AND COSTA; SOARES, 2010; HAN et al., 2004; MAGINN et al., 2009). For example, PE investors should consider not only the expected return for the final decision, but also specific criteria related to the projects being considered such as investment strategy, internal regulations, cost structure, financial commitment from the main manager, funding stage, previous performance, quality of management team, talent retention policy and social networking, among others. In other words, limited partners need to make decisions in the face of a problem characterized by multiple decision criteria (EHGOTT; FIGUEIRA; GRECO, 2010; ZAVADSKAS; TURSKIS, 
2011). Multicriteria decision-making methodologies are particularly useful when facing a problem with multiple conflicting criteria (CLEMEN; REILLY, 2001; GOMES; ARAYA; CARIGNANO, 2004; WALLENIUS et al., 2008).

Several applications of multicriteria decision-making methodologies to finance are documented (HALLERBACH; SPRONK, 2002; MATSATSINIS; DOUMPOS; ZOPOUNIDIS, 1997; STEUER; NA, 2003; XIDONAS et al., 2012; ZOUPONIDIS, 1999). The two problems that have deserved a greater dedication by researchers to date are:

1. Credit analysis, as illustrated by Doumpos \& Zopounidis (2010, 2011), Sahajwala e Van den Bergh (2000) and Zopounidis and Doumpos(1998).

2. Asset selection, as illustrated by Steuer, Qi and Hirschberger (2007), Xidonas, Mavrotas, Zopounidis and Psarras(2011) and Zopounidis, Doumpos and Zanakis(1999) for the European financial market, and Duarte and Lisboa (2013) and Sant'Anna, Nogueira andRabelo (2011) for the Brazilian financial market.

There is currently no literature documenting the use of multi-criteria methods specifically for the analysis and selection of investments in PE, neither in Brazil, nor abroad.

The object of study of this article is the selection of PE investment funds with the use of multicriteria decision-making methodologies. In other words, in order to identify a set of PE funds in the Brazilian financial market for possible investment, as well as a set of criteria for comparing these funds, we propose the use of a multicriteria decision-making methodology to sort the funds, finally selecting those mostly identified with the preferences revealed by the investor. For illustration purposes, we base the methodology proposed in this article on the Technique for Order of Preference by Similarity to Ideal Solution method (TOPSIS; HWANG; YOON, 1981; YOON, 1987; YOON; HWANG, 1995). Once the order of PE funds has been established (which is obtained after applying the TOPSIS method to the data), the investor must select into how many funds he wants to allocate resources according to the optimal number of funds for future monitoring, the amounts available for allocation, the investment policy, among other reasons related specifically to his reality. As an illustrative example, we considered the problem of selecting among eleven PE funds offered to institutional investors in the Brazilian market at the end of 2013, using to that end twenty two criteria.

In terms of organization, in the next section we outline the methodology for the selection of PE funds in Brazil. The details of the methodology are presented in the three 
following sections, starting with the description of the twenty two criteria adopted for comparing the PE funds. In the fourth section, we present the data of the eleven PE funds offered to one of the largest Brazilian pension funds at the end of 2013, the FAPES/BNDES, as well as the use of the methodology, step by step, until the final ordering of alternatives is obtained. Several sensitivity analyses are presented in the fifth section to illustrate how small disturbances in the initial parameters can impact the final ordering of PE funds. Finally, our conclusions and future directions close this article.

\section{A MULTI-CRITERIA METHODOLOGY FOR THE SELECTION OF PRIVATE EQUITY FUNDS}

The methodology proposed in this section allows the decision maker to select PE funds for possible investment based on a set of criteria, in line with their preferences, based on a multicriteria decision-making method.

The methodology is structured in five steps:

1. Defining the set with all PE funds considered for possible investment. For example, in the case of a pension fund, this list is usually generated by the research area after contact with the commercial area of fund managers available on the market. Once a first presentation by the commercial area of the PE fund is made, various data are collected, and a due diligence process is conducted for each fund. At the end, there will be a list of all the funds being considered for investment and their main information, duly organized. In the numerical example presented ahead we use eleven PE funds that were available for investment at the end of 2013.

2. Construction of a set of criteria based on elements that should direct the comparative analysis between the PE funds considered for investment. Criteria must be relevant (to facilitate the comparison of possible investments), independent (to produce rankings minimally affected by other criteria) and operational (easy to obtain and interpret). There is no optimum number of criteria to be adopted, and it is the decision maker who must define it, provided that the three mentioned characteristics (relevance, independence and operability) are respected. In the numerical example presented forth we use the total of twenty two criteria.

3. Determining the relative importance (or weight) of the criteria according to the opinion of the decision maker. Obtaining the weights is an important stage, and should require performing a sensitivity analyses later in order to measure how small changes in the relative importance established for the criteria can alter the final ordering. 
4. The application of a multicriteria decision-making method for the ordering of PE funds in line with preferences revealed by the investor. The application of a multicriteria method facilitates the identification of best investment alternatives (and, therefore, the identification of worst alternatives as well). In other words, the use of a multicriteria method facilitates the decision-making process, making the discussion more objective, focused on the most interesting funds and aligned with the criteria and preferences revealed by the decision maker.

5. Final choice of the PE funds for investment. Analysts who are responsible for the analysis and ordering of funds must now present their results for the investment committee. Finally, the committee will select some funds for investment, with the respective amounts to be allocated.

In the following three sections we detail the methodology, as well as illustrate its application with real data.

\section{CRITERIA FOR THE ANALYSIS OF PRIVATE EQUITY FUNDS}

An important step towards the use of the methodology proposed is the specification of the criteria used for the comparison of PE funds.

The criteria used for the selection of PE funds are usually qualitative/judgmental (LOPES; FURTADO, 2006), unlike quantitative criteria (accounting, financial and economic), commonly used during the fundamental analysis of stocks (DAMODARAN, 2012; STOWE et al., 2007) and bonds (FABOZZI, 2012; TUCKMAN, SERRAT, 2011). The reason for this difference is that $\mathrm{PE}$ funds do not present historical records available during the initial phases, whereas in the fundamental analysis of stocks and bonds the issuing companies have, for example, audited balance sheets and a long history of operations in the market.

The twenty-two criteria we suggest to analyze PE investments in Brazil are (see also Table 1):

1. The first group of criteria is related to the characteristics of the managing company, especially with regards to its history, financial sustainability, professional network and market reputation, among other points.

In this first group we have: 
a. Proven experience with PE. It seeks to verify how many years the managing company has been operating in the PE market. The longer it has operated, the better should be the judgment of the PE fund.

b. Completed cycles in the market. It looks into whether the managing company was able, at some point, to complete a cycle - raising financial resources, investing in companies, followed by the total disinvestment with distribution of results for investors. The more cycles completed, the better should be the judgment of the PE fund.

c. History. It looks into the results generated for their previous investors. As the history of Brazilian PE market is still limited, only a very small number of managing companies have a history of results, but, if any, companies with good historical performance should be favored.

d. Financial sustainability. It seeks to verify the financial sustainability of the managing company over the expected existence of the PE fund, considering other possible sources of income (for the managing company). The lower the financial dependency of the managing company on the PE fund, the more solid should be considered the financial sustainability of the company.

e. Financial commitment of the managing company towards the fund. It seeks to verify the alignment of interests and commitment in the pursuit of the best possible results for the $\mathrm{PE}$ fund by the managing company. A small participation in the PE fund (by the managing company) must be considered as positive. On the other hand, huge investments in the PE fund (by the managing company) require attention because the managing company may control the investors' assemblies, which can result in a poor corporate governance structure, given the potential conflicts of interest: for example, if the managing company decides to call a meeting to decide on the increase of management fees, thus improving their own remuneration, it is most likely that other investors may not like the result. In principle, the greater the managing company participation, the better, as long as this participation does not exceed an amount that will allow it to control decisions related to the fund.

f. Relationship network. It seeks to verify whether there is a good relationship network to originate new investment opportunities for the fund. The larger the relationship network, the better should be the evaluation of the managing company. 
2. The second group of criteria is related to members of the fund management team, considering their dedication, experience and history working together, among other points. In this second group of criteria we have:

a. Team dedication. It seeks to verify the dedication to the management of the PE fund. The greater the dedication, the better should be the evaluation of the fund.

b. Individual experience in PE. It seeks to verify the experience of team members in the PE market (Brazil or abroad). It is interesting that team members have lived other experiences in the PE market, which may now serve as a learning experience for possible uncertainties they might face during the current management. The more people with experience in PE, the better should be the assessment of the PE fund.

c. Length of time working together. It seeks to verify the length of time in which the team has been working together, as well as its cohesion. People who have worked together for a long period must receive the best evaluation, as this is an indication of greater cohesion, alignment of interests and mutual professional respect, facilitating personal relationships, and ensuring stability when teamwork is necessary for the proper performance of the fund. The longer the length of time working together, the better should be the evaluation conferred to the fund.

d. The team's profile adherence to the orientation of the PE fund. It seeks to verify whether the team's professional profile is compatible with the focus of the fund. For example, for funds focused on some specific economic sector it is recommended that members of the management team should have great experience in the sector, even though the managing company might use outside consulting services. In other words, it is important to have people who have worked and undertaken executive positions in companies from the same economic sector of interest to the PE fund. The greater the management team's perceived adherence in relation to the PE fund orientation, the better should be the evaluation.

e. Talent retention policy. It seeks to verify whether the remuneration policies (fixed and variable) is attractive for the team and consistent with the expected maturity of the fund. In the specific case of a PE fund, the retention policy is critical to keep the team up until the stage of disinvestment, since results only 
begin to be received close to the funds liquidation and therefore, the team must wait for greater remuneration to be distributed as a "bonus". If there is no coherent alignment, it is likely for some professionals to leave the team before the disinvestment stage, which may compromise final returns for investors. The more appropriate the talent retention policy is considered to be, the better should be the evaluation received by the fund.

f. Practitioners turnover rate. It seeks to verify whether the managing company shows a high rate of employment and loss of practitioners to the market. Let us remember that when investors decide to invest resources in a PE fund, one of the main reasons for the choice is related to the quality of the management team. Therefore, any change of staff can affect the management of the fund, possibly compromising the profitability expected by investors. PE funds with low turnover rates of practitioners should be viewed as better than those with high turnover of practitioners.

3. The PE fund's investment thesis is related to the third set of proposed criteria, covering points related to the way in which the manager intends to provide earnings for the investors. The investment thesis is also related to the fund's attractiveness on the basis of, for example, their market expectations and diversification of investments.

a. Investment strategy. It seeks to verify whether the thesis presented by managers makes sense taking into account the number of companies being considered for investment, size of the idealized fund, investment ticket per company, profile of companies in the sector, geographic region, managers' focus and macroeconomic environment. The more coherent the adopted investment strategy is, the better should be the PE fund be considered.

b. Attractiveness. It seeks to verify whether the fund fits the investor's interest according to the amounts available for investment, economic sectors of interest, current portfolio diversification and desired maturity. Let us remember that investors have different interests and profiles and, therefore, a fund deemed interesting by an investor may not be interesting to another. The closer to the investor's interests, the better should be the judgment assigned to the fund.

4. The fourth group of criteria is related to the investment process, from the investment decision-making process, to the retrieval of investments made by the PE fund. 
a. Decision process. It seeks to verify the different steps through which an investment proposal goes in the managing company, including decisionmaking agents, periodicity, coherence of the process and segregation in relation to the managers' investment. The better structured the decisionmaking process is considered to be, the better should be the assessment granted to the PE fund.

b. Exit strategy. It seeks to verify whether the exit alternatives for investors are coherent. The better the exit process is designed, the better should be the assessment of the PE Fund.

5. In the group of criteria related to the financial aspects of the PE fund, we analyze whether the fund is financially viable and whether the fees are compatible with the PE market.

a. Structure of revenues and costs, and fees. It seeks to verify whether the management fee is sufficient to cover the fund's costs, and whether the performance fee effectively encourages the manager to outperform. In other words, we must analyze the compatibility of rates (management and performance) with the costs of the fund, and if they are in accordance with market practices. If the values of the rates are compatible with market values and stimulate the management performance, the PE fund must receive a good assessment.

b. Financial resource raising stage. It seeks to verify the fund's attractiveness to potential investors before its closing. This aspect is important because many managers tend to test the market to see if their funds seem to be interesting and, only after the first market responses, they effectively begin the stages of creation and financial fund raising. For the investor, it is important to disregard immediately PE funds that are not well established. PE funds in the most advanced stage of fund raising should be preferred in the analysis.

6. The sixth group of criteria considers where the PE fund intends to invest (usually called the fund's pipeline). The essence of this criterion is whether the manager can pick companies to invest in line with the PE fund investment thesis. Naturally, throughout the existence of the fund other interesting opportunities may appear, or some of the companies considered interesting initially may reveal to be not as promising as in the beginning. In this criteria group we have: 
a. Quality and alignment with the fund's focus. It seeks to verify whether investments are aligned with the investment's policy. For example, if a PE supposed to invest in agribusiness presents in its pipeline an education company, we have a situation of misalignment. As a second example, if a company proposes to invest in companies in the northeast of Brazil, it makes no sense to consider investments in the southern region of the country. We must also be analyze the growth potential of the activity sector of the companies considered for the investment, existence of competition and anticipated market share. The more aligned investee companies are in relation to the investment thesis, the better should be the evaluation of the fund.

b. Analysis and negotiation stage. It seeks to verify the PE fund stage of understanding with the companies indicated in its pipeline, including the relationship of fund managers with entrepreneurs, including if there are any agreements already signed (ensuring priority or exclusivity) or whether there will be a competitive investment process with other funds. The more advanced the negotiation stage is, the better should be the evaluation of the fund.

7. The penultimate group is related to the PE fund's governance structure. In this seventh criteria group we have:

a. Regulation. It seeks to verify the fund's governance structure, deliberation quorums, how do investors participate in the investment committee (responsible for the decision on the acquisition and disposal of assets in the fund), how can conflicts of interest in fund management be solved, procedures for the possible dismissal of the manager and the periodicity of meetings and distribution of voting percentage in each instance. The regulation of the PE fund should be analyzed in comparison to those already in the market, specifying whether it is more detailed or not than the best market practice.

8. The last group is related to any previous investor's experience with the management concerned. In other words, the relationship history between managing company and investor. In this group we have:

a. Previous investments with the managing company and/or team. It seeks to verify on experiences (positive or negative) between the managing company and its team in the past. Even though a past experience may not guarantee a good future performance, these cannot be ignored in new investments, especially if these have been negative with regards to the availability of 
information (transparency) and results obtained. A fund should be better evaluated if it has generated positive past experiences.

\begin{tabular}{|c|c|c|c|c|c|}
\hline Criteria & $\mathbf{E}$ & D & $\mathbf{C}$ & B & $\mathbf{A}$ \\
\hline \multicolumn{6}{|l|}{ Fund Manager } \\
\hline $\begin{array}{c}\text { Proven experience with } \\
\text { PE } \\
\end{array}$ & less than 1 year & $\begin{array}{c}\text { from } 1 \text { to } 3 \\
\text { years }\end{array}$ & $\begin{array}{c}\text { from } 3 \text { to } 5 \\
\text { years }\end{array}$ & $\begin{array}{c}\text { from } 5 \text { to } 10 \\
\text { years }\end{array}$ & $\begin{array}{c}\text { over } 10 \\
\text { years }\end{array}$ \\
\hline $\begin{array}{c}\text { Completed a cycle for a } \\
\text { PE fund }\end{array}$ & none & only 1 fund & 2 funds & 3 funds & $\begin{array}{l}\text { over } 3 \\
\text { funds }\end{array}$ \\
\hline History of results & none & & $\begin{array}{l}\text { the invested } \\
\text { capital has } \\
\text { not been } \\
\text { returned yet } \\
\text { or it has not } \\
\text { exceeded the } \\
\text { benchmark }\end{array}$ & & $\begin{array}{l}\text { yes, the } \\
\text { invested } \\
\text { capital has } \\
\text { been } \\
\text { returned } \\
\text { and } \\
\text { exceeded } \\
\text { the } \\
\text { benchmark }\end{array}$ \\
\hline Financial sustainability & $\begin{array}{l}\text { unable to sustain itself } \\
\text { without the fund }\end{array}$ & & $\begin{array}{c}\text { fund } \\
\text { manager has } \\
\text { other sources } \\
\text { of revenue, } \\
\text { and the } \\
\text { general } \\
\text { partners do } \\
\text { not intend to } \\
\text { use own } \\
\text { resources in } \\
\text { case of need }\end{array}$ & & $\begin{array}{c}\text { Fund } \\
\text { manager } \\
\text { has other } \\
\text { sources of } \\
\text { revenue in } \\
\text { addition to } \\
\text { the } \\
\text { resources of } \\
\text { general } \\
\text { partners if } \\
\text { necessary }\end{array}$ \\
\hline $\begin{array}{l}\text { Financial commitment of } \\
\text { the manager to the fund }\end{array}$ & $\begin{array}{l}\text { none or very high } \\
\text { (allowing full control } \\
\text { of investors' } \\
\text { assemblies) }\end{array}$ & $\begin{array}{l}\text { less than } \\
1 \% \text { of the } \\
\text { fund's } \\
\text { equity }\end{array}$ & $\begin{array}{c}\text { between } 1 \% \\
\text { and } 5 \% \text { of } \\
\text { the fund's } \\
\text { equity }\end{array}$ & $\begin{array}{c}\text { between } 5 \% \\
\text { and } 10 \% \text { of } \\
\text { the fund's } \\
\text { equity }\end{array}$ & $\begin{array}{l}\text { more than } \\
10 \% \text { of the } \\
\text { fund equity, } \\
\text { but without } \\
\text { full control } \\
\text { of the fund }\end{array}$ \\
\hline Relationship network & under construction & & $\begin{array}{l}\text { established } \\
\quad \text { and } \\
\text { considered } \\
\text { reasonable }\end{array}$ & & $\begin{array}{l}\text { established } \\
\text { and } \\
\text { considered } \\
\text { good }\end{array}$ \\
\hline \multicolumn{6}{|l|}{ Team } \\
\hline Fund's Team Dedication & $\begin{array}{l}\text { dedication not } \\
\text { specified }\end{array}$ & $\begin{array}{l}\text { specified, } \\
\text { but } \\
\text { dedication } \\
\text { is } \\
\text { insufficient }\end{array}$ & $\begin{array}{l}\text { specified and } \\
\text { the team's } \\
\text { dedication is } \\
\text { acceptable }\end{array}$ & & $\begin{array}{l}\text { specified } \\
\text { and team is } \\
\text { fully } \\
\text { dedicated to } \\
\text { the fund }\end{array}$ \\
\hline $\begin{array}{c}\text { Individual experience in } \\
\text { PE }\end{array}$ & $\begin{array}{l}\text { no team member with } \\
\text { experience }\end{array}$ & $\begin{array}{l}\text { less than } \\
25 \% \text { of the } \\
\text { team with } \\
\text { experience }\end{array}$ & $\begin{array}{l}\text { between } \\
25 \% \text { and } \\
50 \% \text { of the } \\
\text { team with } \\
\text { experience }\end{array}$ & $\begin{array}{l}\text { between } 50 \% \\
\text { and } 75 \% \text { of } \\
\text { the team with } \\
\text { experience }\end{array}$ & $\begin{array}{l}\text { more than } \\
75 \% \text { of the } \\
\text { team with } \\
\text { experience }\end{array}$ \\
\hline $\begin{array}{c}\text { Lenght of time working } \\
\text { together }\end{array}$ & less than 1 year & $\begin{array}{c}\text { from } 1 \text { to } 3 \\
\text { years }\end{array}$ & $\begin{array}{c}\text { from } 3 \text { to } 5 \\
\text { years }\end{array}$ & $\begin{array}{c}\text { from } 5 \text { to } 10 \\
\text { years }\end{array}$ & $\begin{array}{c}\text { above } 10 \\
\text { years }\end{array}$ \\
\hline $\begin{array}{l}\text { Adherence of the team's } \\
\text { profile focus to the fund }\end{array}$ & $\begin{array}{l}\text { no team member with } \\
\text { experience }\end{array}$ & $\begin{array}{l}\text { less than } \\
25 \% \text { of the } \\
\text { team with } \\
\text { experience }\end{array}$ & $\begin{array}{l}\text { between } \\
25 \% \text { and } \\
50 \% \text { of the } \\
\text { team with } \\
\text { experience }\end{array}$ & $\begin{array}{l}\text { between } 50 \% \\
\text { and } 75 \% \text { of } \\
\text { the team with } \\
\text { experience }\end{array}$ & $\begin{array}{l}\text { more than } \\
75 \% \text { of the } \\
\text { team with } \\
\text { experience }\end{array}$ \\
\hline
\end{tabular}




\begin{tabular}{|c|c|c|c|c|c|}
\hline Talent retention policy & no retention policy & & \begin{tabular}{|} 
existent, but \\
policy \\
considered \\
as \\
insufficient \\
\end{tabular} & & $\begin{array}{c}\text { existent and } \\
\text { satisfactory } \\
\text { policy }\end{array}$ \\
\hline $\begin{array}{c}\text { Practitioners' turnover } \\
\text { rate }\end{array}$ & $\begin{array}{l}\text { turnover considered } \\
\text { high }\end{array}$ & & $\begin{array}{l}\text { turnover } \\
\text { considered } \\
\text { moderate }\end{array}$ & & $\begin{array}{c}\text { turnover } \\
\text { considered } \\
\text { low }\end{array}$ \\
\hline \multicolumn{6}{|l|}{ Investment Thesis } \\
\hline Investment strategy & strategy incoherent & & $\begin{array}{c}\text { strategy } \\
\text { acceptable }\end{array}$ & & $\begin{array}{l}\text { excellent } \\
\text { strategy }\end{array}$ \\
\hline Atractiveness & low & & medium & & high \\
\hline \multicolumn{6}{|l|}{ Investment Process } \\
\hline Decision making process & nonexistent & & $\begin{array}{c}\text { structured, } \\
\text { with some } \\
\text { flaws }\end{array}$ & & $\begin{array}{c}\text { well } \\
\text { structured }\end{array}$ \\
\hline Exit strategy & incoherent & & $\begin{array}{l}\text { coherent, but } \\
\text { with } \\
\text { possible } \\
\text { problems }\end{array}$ & & $\begin{array}{l}\text { coherent, } \\
\text { with no } \\
\text { anticipated } \\
\text { problems } \\
\end{array}$ \\
\hline \multicolumn{6}{|l|}{ Financial aspects } \\
\hline $\begin{array}{l}\text { Structure of revenues and } \\
\text { costs, and fees charged }\end{array}$ & unbalanced & & & & $\begin{array}{l}\text { balanced } \\
\text { and in line } \\
\text { with the } \\
\text { market }\end{array}$ \\
\hline Fund raising stage & $\begin{array}{l}\text { no registration with } \\
\text { the CVM }\end{array}$ & $\begin{array}{l}\text { registered } \\
\text { with the } \\
\text { CVM, but } \\
\text { without } \\
\text { funding }\end{array}$ & $\begin{array}{c}\text { less than } 1 / 3 \\
\text { raised }\end{array}$ & $\begin{array}{c}\text { from } 1 / 3 \text { and } \\
2 / 3 \text { raised }\end{array}$ & $\begin{array}{l}\text { more than } \\
2 / 3 \text { raised }\end{array}$ \\
\hline \multicolumn{6}{|l|}{ Business for Investments } \\
\hline $\begin{array}{l}\text { Quality and alignment } \\
\text { with th fund's focus }\end{array}$ & $\begin{array}{l}\text { little alignment with } \\
\text { the investment thesis }\end{array}$ & & \begin{tabular}{|c|} 
most \\
companies \\
aligned with \\
the \\
investment \\
thesis \\
\end{tabular} & & \begin{tabular}{|c} 
all \\
businesses \\
in line with \\
the \\
investment \\
thesis
\end{tabular} \\
\hline $\begin{array}{c}\text { Stage of analysis and } \\
\text { negotiation }\end{array}$ & uninitiated & & $\begin{array}{c}\text { initiated with } \\
\text { nothing } \\
\text { signed } \\
\end{array}$ & & advanced \\
\hline \multicolumn{6}{|l|}{ Governance } \\
\hline Regulation & none presented & $\begin{array}{c}\text { it is present, } \\
\text { but lower } \\
\text { than the } \\
\text { industry } \\
\text { standard }\end{array}$ & & $\begin{array}{l}\text { it is present } \\
\text { and follows } \\
\text { the market } \\
\text { standard }\end{array}$ & $\begin{array}{c}\text { it is present } \\
\text { and exceeds } \\
\text { the industry } \\
\text { standard }\end{array}$ \\
\hline \multicolumn{6}{|l|}{ History with the Investor } \\
\hline $\begin{array}{c}\text { Previous investments with } \\
\text { the fund manager and/or } \\
\text { team }\end{array}$ & $\begin{array}{l}\text { yes, disappointing } \\
\text { results }\end{array}$ & & $\begin{array}{l}\text { yes, but } \\
\text { without } \\
\text { earnings } \\
\text { received yet }\end{array}$ & & $\begin{array}{c}\text { yes, } \\
\text { surpassed } \\
\text { benchmark }\end{array}$ \\
\hline
\end{tabular}

Table 1 - Criteria for Private Equity Funds Analysis

Table 1 summarizes the twenty two presented criteria, in addition to specifying how each PE fund must be classified according to each criterion, using scores from "A" (best) to "E" (worst). As an example, let us consider the first criterion: Proven experience with PE. We 
see that the experience of the fund manager with PE should be classified into five levels, the best designated to managers with over ten years of experience in the PE market, "A" score, and the worst designated to those operating for less than a year in the same market, "E" score. A second example is given by the twelfth criteria: Practitioners turnover rate. In this case, we suggest that PE funds be classified with only three scores: score "A", the best possibility, in case the turnover rate is considered to be low (compared to the turnover rate of other PE funds), score "C", intermediate, in case the turnover rate is considered as moderate, and score "E", the worst, in case the turnover rate is considered to be high. A third example is taken from the fourteenth criterion - attractiveness - which is also based on three classification levels: great, regarding the best score "A", medium, regarding an intermediate score, "C", and small, regarding the worst score "E".

\section{A NUMERICAL EXAMPLE}

The TOPSIS method was developed to assist the decision maker to rank alternatives in the face of multiple conflicting criteria. The ten steps that must be followed when TOPSIS is used are summarized in an attachment, at the end of this article, and illustrated in this section with real data.

The first step of the TOPSIS method requires the definition of criteria for the comparison of alternatives, done in the previous section. Twenty two criteria to compare PE funds have been proposed, detonated henceforth as $C_{1}, C_{2}, \ldots, C_{22}$.

The second step consists in specifying alternatives for possible investment. In this article we use real data obtained from the Brazilian financial market. We chose eleven PE funds that were going through the process of raising capital in Brazil at the end of 2013. The eleven funds were interviewed by FAPES's investment managers for possible investment. All data obtained by FAPES and used in the study were given directly by the managers of these PE funds. Other information deemed important by FAPES's investment managers were formally requested and answered (in writing) by fund managers. The eleven funds will be denoted in the remainder of this study as $F_{1}, F_{2}, \ldots, F_{11}$, with their names preserved. Their main characteristics are depicted in Table 2. 
Table 2 - Private Equity Funds for Investments

\begin{tabular}{|c|c|c|c|c|c|c|c|c|c|}
\hline Fund & Type & Objetive & Segment & $\begin{array}{l}\text { Size }(\mathrm{R} \$ \\
\text { millions })\end{array}$ & Benchmark & $\begin{array}{l}\text { Total } \\
\text { period }\end{array}$ & $\begin{array}{l}\text { Investment } \\
\text { Deadline }\end{array}$ & $\begin{array}{l}\text { Business for } \\
\text { Investments }\end{array}$ & $\begin{array}{l}\text { Investment } \\
\text { Committee }\end{array}$ \\
\hline 1 & FIP & $\begin{array}{l}\text { Companies with } \\
\text { average annual } \\
\text { revenues between } \\
\mathrm{R} \$ 300 \text { and } \mathrm{R} \$ 500 \\
\text { million }\end{array}$ & $\begin{array}{c}\text { Infrastruct } \\
\text { ure }\end{array}$ & 700 & $\begin{array}{c}\text { IPCA + 7.5\% } \\
\text { p.a. }\end{array}$ & $\begin{array}{c}10 \\
\text { years }\end{array}$ & 4 years & $\begin{array}{c}\text { Twelve } \\
\text { opportunities }\end{array}$ & $\begin{array}{c}\text { Shareholders } \\
\text { participate in } \\
\text { the } \\
\text { committee }\end{array}$ \\
\hline 2 & FIP & $\begin{array}{l}\text { Companies with } \\
\text { average annual } \\
\text { revenues above } \\
\mathrm{R} \$ 600 \text { million in } \\
\text { difficulties }\end{array}$ & $\begin{array}{c}\text { Diversifie } \\
\mathrm{d}\end{array}$ & 4000 & N/A & N/A & N/A & $\begin{array}{c}\text { Four } \\
\text { opportunities }\end{array}$ & $\begin{array}{c}\text { Shareholders } \\
\text { participate in } \\
\text { the } \\
\text { committee }\end{array}$ \\
\hline 3 & FIP & $\begin{array}{c}\text { Between eight } \\
\text { and ten } \\
\text { companies with } \\
\text { average annual } \\
\text { revenues between } \\
\mathrm{R} \$ 300 \text { and } \mathrm{R} \$ 500 \\
\text { million }\end{array}$ & $\begin{array}{c}\text { Diversifie } \\
\mathrm{d}\end{array}$ & 1000 & $\begin{array}{c}\text { IPCA }+8.5 \% \\
\text { p.a. }\end{array}$ & $\begin{array}{c}10 \\
\text { years }\end{array}$ & 5 years & Various & $\begin{array}{c}\text { Shareholders } \\
\text { participate in } \\
\text { the } \\
\text { committee }\end{array}$ \\
\hline 4 & FIP & $\begin{array}{l}\text { Medium-sized } \\
\text { enterprises }\end{array}$ & $\begin{array}{c}\text { Diversifie } \\
\mathrm{d}\end{array}$ & 300 & $\begin{array}{c}\text { IPCA + } 6.0 \% \\
\text { p.a. }\end{array}$ & $\begin{array}{c}10 \\
\text { years }\end{array}$ & 3 years & N/A & $\begin{array}{c}\text { Shareholders } \\
\text { participate in } \\
\text { the } \\
\text { committee }\end{array}$ \\
\hline 5 & FIP & $\begin{array}{l}\text { Projects in the } \\
\text { energy sector }\end{array}$ & Energy & 400 & $\begin{array}{c}\text { IPCA + } 6.0 \% \\
\text { p.a. }\end{array}$ & $\begin{array}{c}10 \\
\text { years }\end{array}$ & 5 years & $\begin{array}{l}\text { Specific } \\
\text { project } \\
\text { (biomass) }\end{array}$ & $\begin{array}{c}\text { Shareholders } \\
\text { participate in } \\
\text { the } \\
\text { committee }\end{array}$ \\
\hline 6 & FIP & $\begin{array}{l}\text { Medium-sized } \\
\text { enterprises }\end{array}$ & $\begin{array}{c}\text { Diversifie } \\
\mathrm{d}\end{array}$ & 600 & $\begin{array}{c}\text { IPCA + 5.0\% } \\
\text { p.a. }\end{array}$ & $\begin{array}{c}10 \\
\text { years }\end{array}$ & 5 years & Various & $\begin{array}{c}\text { Shareholders } \\
\text { participate in } \\
\text { the } \\
\text { committee }\end{array}$ \\
\hline 7 & FIP & $\begin{array}{c}\text { Up to ten } \\
\text { companies with } \\
\text { minority } \\
\text { shareholding } \\
\end{array}$ & $\begin{array}{c}\text { Diversifie } \\
\mathrm{d}\end{array}$ & 300 & $\begin{array}{c}\text { IPCA + 8.0\% } \\
\text { p.a. }\end{array}$ & 8 years & 4 years & $\begin{array}{c}\text { Six } \\
\text { opportunities }\end{array}$ & $\begin{array}{c}\text { Shareholders } \\
\text { participate in } \\
\text { the } \\
\text { committee }\end{array}$ \\
\hline 8 & FIP & $\begin{array}{l}\text { Small and } \\
\text { Medium } \\
\text { Enterprises }\end{array}$ & $\begin{array}{c}\text { Diversifie } \\
\mathrm{d}\end{array}$ & 500 & $\begin{array}{c}\text { IPCA + 8.0\% } \\
\text { p.a. }\end{array}$ & 8 years & 5 years & N/A & $\begin{array}{l}\text { Shareholders } \\
\text { participate in } \\
\text { the } \\
\text { committee }\end{array}$ \\
\hline 9 & FIP & Forestry projects & Forestry & 200 & $\begin{array}{c}\text { IPCA + 8.0\% } \\
\text { p.a. }\end{array}$ & $\begin{array}{c}15 \\
\text { years }\end{array}$ & 4 years & $\begin{array}{l}\text { Specific } \\
\text { project }\end{array}$ & $\begin{array}{c}\text { Shareholders } \\
\text { participate in } \\
\text { the } \\
\text { committee }\end{array}$ \\
\hline 10 & FIP & Forestry projects & Forestry & 400 & $\begin{array}{c}\text { IPCA }+7.0 \% \\
\text { p.a. }\end{array}$ & $\begin{array}{c}12 \\
\text { years }\end{array}$ & 3 years & Various & $\begin{array}{c}\text { Shareholders } \\
\text { participate in } \\
\text { the } \\
\text { committee }\end{array}$ \\
\hline 11 & FIP & $\begin{array}{l}\text { Companies with } \\
\text { average annual } \\
\text { revenues between } \\
\mathrm{R} \$ 300 \text { and } \mathrm{R} \$ 500 \\
\text { million } \\
\end{array}$ & $\begin{array}{c}\text { Infrastruct } \\
\text { ure }\end{array}$ & 750 & $\begin{array}{c}\text { IPCA + 8.0\% } \\
\text { p.a. }\end{array}$ & $\begin{array}{c}12 \\
\text { years }\end{array}$ & 5 years & $\begin{array}{c}\text { Four } \\
\text { opportunities }\end{array}$ & $\begin{array}{c}\text { Shareholders } \\
\text { participate in } \\
\text { the } \\
\text { committee }\end{array}$ \\
\hline
\end{tabular}

The scores obtained for the eleven PE funds according to each criterion were initially conferred by investment managers responsible for the analysis after a due diligence. After a meeting of the internal committee at FAPES some scores were changed. The scores are summarized in Table 3. For example, we see that the fund $1\left(F_{1}\right)$ received score "A" for the 
first criterion $\left(C_{1}\right.$ i.e., proven experience in $\left.\mathrm{PE}\right)$. A second example is given by fund $7\left(F_{7}\right)$ which received score " $\mathrm{B}$ " for the twenty-first criterion $\left(C_{21}\right.$ i.e., regulation). A third example is given by fund $11\left(F_{11}\right)$ which received score "A" for the eleventh criterion $\left(C_{11}\right.$ i.e., talent retention policy).

Table 3 - Funds Concepts for Each Criterion

\begin{tabular}{|c|c|c|c|c|c|c|c|c|c|c|c|c|}
\hline & Criteria & Fund 1 & Fund 2 & Fund 3 & Fund 4 & Fund 5 & Fund 6 & Fund 7 & Fund 8 & Fund 9 & $\begin{array}{c}\text { Fund } \\
10\end{array}$ & $\begin{array}{c}\text { Fund } \\
11\end{array}$ \\
\hline & $\begin{array}{c}\text { GestoraFund } \\
\text { manager }\end{array}$ & & & & & & & & & & & \\
\hline 1 & $\begin{array}{c}\text { Proven experience } \\
\text { with PE }\end{array}$ & A & A & A & A & $\mathrm{C}$ & A & E & B & $\mathrm{C}$ & $\mathrm{D}$ & A \\
\hline 2 & $\begin{array}{c}\text { Completed a cycle for } \\
\text { a PE fund }\end{array}$ & $\mathrm{D}$ & $\mathrm{D}$ & A & B & $\mathrm{E}$ & $\mathrm{E}$ & $\mathrm{E}$ & $\mathrm{E}$ & $\mathrm{E}$ & $\mathrm{E}$ & B \\
\hline 3 & History of results & A & A & A & A & $\mathrm{E}$ & $\mathrm{C}$ & E & E & $\mathrm{E}$ & $\mathrm{E}$ & A \\
\hline 4 & $\begin{array}{c}\text { Financial } \\
\text { sustainability }\end{array}$ & A & A & A & A & A & A & E & A & A & E & A \\
\hline 5 & $\begin{array}{c}\text { Financial } \\
\text { commitment of the } \\
\text { manager to the fund }\end{array}$ & $\mathrm{D}$ & A & B & A & $\mathrm{E}$ & $\mathrm{D}$ & $\mathrm{C}$ & $\mathrm{D}$ & $\mathrm{C}$ & $\mathrm{D}$ & $\mathrm{D}$ \\
\hline 6 & Relationship network & A & A & A & A & $\mathrm{C}$ & $\mathrm{C}$ & $\mathrm{C}$ & $\mathrm{C}$ & $\mathrm{C}$ & $\mathrm{C}$ & $\mathrm{C}$ \\
\hline & Team & & & & & & & & & & & \\
\hline 7 & $\begin{array}{c}\text { Fund's Team } \\
\text { Dedication }\end{array}$ & $\mathrm{D}$ & $\mathrm{D}$ & $\mathrm{C}$ & $\mathrm{C}$ & $\mathrm{E}$ & A & $\mathrm{C}$ & $\mathrm{D}$ & $\mathrm{C}$ & $\mathrm{C}$ & $\mathrm{E}$ \\
\hline 8 & $\begin{array}{c}\text { Individual experience } \\
\text { in PE }\end{array}$ & $\mathrm{C}$ & $\mathrm{C}$ & B & $\mathrm{C}$ & $\mathrm{C}$ & A & $\mathrm{D}$ & $\mathrm{D}$ & $\mathrm{C}$ & $\mathrm{D}$ & $\mathrm{C}$ \\
\hline 9 & $\begin{array}{c}\text { Lenght of time } \\
\text { working together }\end{array}$ & $\mathrm{C}$ & $\mathrm{C}$ & $\mathrm{C}$ & $\mathrm{C}$ & $\mathrm{E}$ & $\mathrm{C}$ & $\mathrm{E}$ & $\mathrm{C}$ & $\mathrm{D}$ & B & $\mathrm{D}$ \\
\hline 10 & $\begin{array}{c}\text { Adherence of the } \\
\text { team's profile focus to } \\
\text { the fund }\end{array}$ & $\mathrm{C}$ & $\mathrm{D}$ & B & $\mathrm{C}$ & $\mathrm{D}$ & B & $\mathrm{D}$ & $\mathrm{D}$ & $\mathrm{C}$ & B & B \\
\hline 11 & $\begin{array}{c}\text { Talent retention } \\
\text { policy }\end{array}$ & $\mathrm{C}$ & $\mathrm{C}$ & A & $\mathrm{C}$ & $\mathrm{E}$ & $\mathrm{C}$ & $\mathrm{E}$ & $\mathrm{E}$ & $\mathrm{C}$ & $\mathrm{C}$ & A \\
\hline 12 & $\begin{array}{l}\text { Practitioners' } \\
\text { turnover rate }\end{array}$ & $\mathrm{C}$ & $\mathrm{C}$ & A & $\mathrm{C}$ & $\mathrm{E}$ & $\mathrm{C}$ & $\mathrm{E}$ & $\mathrm{E}$ & $\mathrm{C}$ & $\mathrm{E}$ & $\mathrm{C}$ \\
\hline & Investment Thesis & & & & & & & & & & & \\
\hline 13 & Investment strategy & $\mathrm{C}$ & $\mathrm{C}$ & $\mathrm{C}$ & $\mathrm{C}$ & $\mathrm{C}$ & A & A & $\mathrm{C}$ & $\mathrm{C}$ & $\mathrm{E}$ & $\mathrm{C}$ \\
\hline 14 & Atractiveness & $\mathrm{C}$ & $\mathrm{C}$ & $\mathrm{E}$ & A & A & A & A & A & $\mathrm{E}$ & $\mathrm{E}$ & $\mathrm{C}$ \\
\hline & Investment Process & & & & & & & & & & & \\
\hline 15 & $\begin{array}{c}\text { Decision making } \\
\text { process }\end{array}$ & A & A & $\mathrm{C}$ & $\mathrm{C}$ & $\mathrm{E}$ & $\mathrm{C}$ & $\mathrm{C}$ & $\mathrm{E}$ & $\mathrm{C}$ & $\mathrm{E}$ & A \\
\hline 16 & Exit strategy & $\mathrm{C}$ & $\mathrm{C}$ & $\mathrm{C}$ & A & $\mathrm{C}$ & A & $\mathrm{C}$ & $\mathrm{C}$ & $\mathrm{C}$ & $\mathrm{C}$ & $\mathrm{C}$ \\
\hline & Financial aspects & & & & & & & & & & & \\
\hline 17 & $\begin{array}{c}\text { Structure of revenues } \\
\text { and costs, and fees } \\
\text { charged }\end{array}$ & $\mathrm{E}$ & $\mathrm{E}$ & A & $\mathrm{E}$ & A & A & A & $\mathrm{E}$ & A & A & A \\
\hline 18 & Fund raising stage & $\mathrm{D}$ & $\mathrm{D}$ & $\mathrm{C}$ & $\mathrm{C}$ & $\mathrm{E}$ & $\mathrm{B}$ & $\mathrm{D}$ & $\mathrm{D}$ & $\mathrm{D}$ & $\mathrm{D}$ & $\mathrm{C}$ \\
\hline & $\begin{array}{l}\text { Business for } \\
\text { Investments }\end{array}$ & & & & & & & & & & & \\
\hline 19 & $\begin{array}{l}\text { Quality and } \\
\text { alignment with th } \\
\text { fund's focus }\end{array}$ & E & A & $\mathrm{C}$ & $\mathrm{E}$ & A & A & A & A & $\mathrm{C}$ & $\mathrm{C}$ & A \\
\hline
\end{tabular}




\begin{tabular}{c|c|c|c|c|c|c|c|c|c|c|c|c}
\hline 20 & $\begin{array}{c}\text { Stage of analysis and } \\
\text { negotiation }\end{array}$ & $\mathrm{C}$ & $\mathrm{E}$ & $\mathrm{A}$ & $\mathrm{E}$ & $\mathrm{A}$ & $\mathrm{A}$ & $\mathrm{A}$ & $\mathrm{A}$ & $\mathrm{A}$ & $\mathrm{A}$ & $\mathrm{A}$ \\
\hline Governance & & & & & & & & & & & \\
\hline 21 & Regulation & $\mathrm{E}$ & $\mathrm{E}$ & $\mathrm{B}$ & $\mathrm{D}$ & $\mathrm{E}$ & $\mathrm{B}$ & $\mathrm{B}$ & $\mathrm{D}$ & $\mathrm{E}$ & $\mathrm{E}$ & $\mathrm{E}$ \\
\hline $\begin{array}{c}\text { History with the } \\
\text { Investor }\end{array}$ & & & & & & & & & & & \\
\hline $\begin{array}{c}\text { Previous investments } \\
\text { with the fund } \\
\text { manager and/or team }\end{array}$ & $\mathrm{C}$ & $\mathrm{C}$ & $\mathrm{E}$ & $\mathrm{E}$ & $\mathrm{E}$ & $\mathrm{C}$ & $\mathrm{E}$ & $\mathrm{E}$ & $\mathrm{E}$ & $\mathrm{E}$ & $\mathrm{E}$ \\
\hline
\end{tabular}

For the application of TOPSIS, the scores in Table 3 must be converted using a numerical scale. For this first numerical example we established that " $A$ " will be quantified as 5 , score "B" as 4, and so on, until score "E", quantified as 1 . Naturally, the choice of this numeric scale (from 5 to 1 ) may influence the final ordering obtained with TOPSIS, this being the reason why we will present a sensitivity analysis latter in this article for this scale. Table 4 summarizes the conversion of scores (given in Table 3 ) into their numerical values.

Table 4 - Funds' Scores from Each Criterion

\begin{tabular}{|c|c|c|c|c|c|c|c|c|c|c|c|c|}
\hline & Criteria & Fund 1 & Fund 2 & Fund 3 & Fund 4 & Fund 5 & Fund 6 & Fund 7 & Fund 8 & Fund 9 & \begin{tabular}{|c|} 
Fund \\
10 \\
\end{tabular} & \begin{tabular}{|c} 
Fund \\
11
\end{tabular} \\
\hline & Fund manager & & & & & & & & & & & \\
\hline 1 & $\begin{array}{c}\text { Proven } \\
\text { experience } \\
\text { with } \mathbf{P E} \\
\end{array}$ & 5 & 5 & 5 & 5 & 3 & 5 & 1 & 4 & 3 & 2 & 5 \\
\hline 2 & $\begin{array}{c}\text { Completed a } \\
\text { cycle for a PE } \\
\text { fund } \\
\end{array}$ & 2 & 2 & 5 & 4 & 1 & 1 & 1 & 1 & 1 & 1 & 4 \\
\hline 3 & $\begin{array}{c}\text { History of } \\
\text { results }\end{array}$ & 5 & 5 & 5 & 5 & 1 & 3 & 1 & 1 & 1 & 1 & 5 \\
\hline 4 & $\begin{array}{c}\text { Financial } \\
\text { sustainability }\end{array}$ & 5 & 5 & 5 & 5 & 5 & 5 & 1 & 5 & 5 & 1 & 5 \\
\hline 5 & $\begin{array}{c}\text { Financial } \\
\text { commitment of } \\
\text { the manager to } \\
\text { the fund }\end{array}$ & 2 & 5 & 4 & 5 & 1 & 2 & 3 & 2 & 3 & 2 & 2 \\
\hline 6 & $\begin{array}{c}\text { Relationship } \\
\text { network }\end{array}$ & 5 & 5 & 5 & 5 & 3 & 3 & 3 & 3 & 3 & 3 & 3 \\
\hline & Team & & & & & & & & & & & \\
\hline 7 & $\begin{array}{c}\text { Fund's Team } \\
\text { Dedication }\end{array}$ & 2 & 2 & 3 & 3 & 1 & 5 & 3 & 2 & 3 & 3 & 1 \\
\hline 8 & $\begin{array}{c}\text { Individual } \\
\text { experience in } \\
\text { PE } \\
\end{array}$ & 3 & 3 & 4 & 3 & 3 & 5 & 2 & 2 & 3 & 2 & 3 \\
\hline 9 & $\begin{array}{c}\text { Lenght of time } \\
\text { working } \\
\text { together }\end{array}$ & 3 & 3 & 3 & 3 & 1 & 3 & 1 & 3 & 2 & 4 & 2 \\
\hline 10 & $\begin{array}{c}\text { Adherence of } \\
\text { the team's } \\
\text { profile focus to } \\
\text { the fund }\end{array}$ & 3 & 2 & 4 & 3 & 2 & 4 & 2 & 2 & 3 & 4 & 4 \\
\hline 11 & $\begin{array}{c}\text { Talent } \\
\text { retention } \\
\text { policy } \\
\end{array}$ & 3 & 3 & 5 & 3 & 1 & 3 & 1 & 1 & 3 & 3 & 5 \\
\hline 12 & $\begin{array}{l}\text { Practitioners' } \\
\text { turnover rate }\end{array}$ & 3 & 3 & 5 & 3 & 1 & 3 & 1 & 1 & 3 & 1 & 3 \\
\hline & $\begin{array}{c}\text { Investment } \\
\text { Thesis }\end{array}$ & & & & & & & & & & & \\
\hline
\end{tabular}




\begin{tabular}{|c|c|c|c|c|c|c|c|c|c|c|c|c|}
\hline 13 & $\begin{array}{c}\text { Investment } \\
\text { strategy }\end{array}$ & 3 & 3 & 3 & 3 & 3 & 5 & 5 & 3 & 3 & 1 & 3 \\
\hline \multirow[t]{3}{*}{14} & Atractiveness & 3 & 3 & 1 & 5 & 5 & 5 & 5 & 5 & 1 & 1 & 3 \\
\hline & $\begin{array}{c}\text { Investment } \\
\text { Process }\end{array}$ & & & & & & & & & & & \\
\hline & $\begin{array}{c}\text { Decision } \\
\text { making } \\
\text { process } \\
\end{array}$ & 5 & 5 & 3 & 3 & 1 & 3 & 3 & 1 & 3 & 1 & 5 \\
\hline \multirow[t]{3}{*}{16} & Exit strategy & 3 & 3 & 3 & 5 & 3 & 5 & 3 & 3 & 3 & 3 & 3 \\
\hline & $\begin{array}{c}\text { Financial } \\
\text { aspects }\end{array}$ & & & & & & & & & & & \\
\hline & $\begin{array}{c}\text { Structure of } \\
\text { revenues and } \\
\text { costs, and fees } \\
\text { charged }\end{array}$ & 1 & 1 & 5 & 1 & 5 & 5 & 5 & 1 & 5 & 5 & 5 \\
\hline \multirow[t]{2}{*}{18} & $\begin{array}{c}\text { Fund raising } \\
\text { stage }\end{array}$ & 2 & 2 & 3 & 3 & 1 & 4 & 2 & 2 & 2 & 2 & 3 \\
\hline & $\begin{array}{l}\text { Business for } \\
\text { Investments }\end{array}$ & & & & & & & & & & & \\
\hline 19 & $\begin{array}{l}\text { Quality and } \\
\text { alignment with } \\
\text { th fund's focus }\end{array}$ & 1 & 5 & 3 & 1 & 5 & 5 & 5 & 5 & 3 & 3 & 5 \\
\hline \multirow[t]{2}{*}{20} & $\begin{array}{c}\text { Stage of } \\
\text { analysis and } \\
\text { negotiation }\end{array}$ & 3 & 1 & 5 & 1 & 5 & 5 & 5 & 5 & 5 & 5 & 5 \\
\hline & Governance & & & & & & & & & & & \\
\hline \multirow[t]{3}{*}{21} & Regulation & 1 & 1 & 4 & 2 & 1 & 4 & 4 & 2 & 1 & 1 & 1 \\
\hline & $\begin{array}{l}\text { History with } \\
\text { the Investor }\end{array}$ & & & & & & & & & & & \\
\hline & $\begin{array}{c}\text { Previous } \\
\text { investments } \\
\text { with the fund } \\
\text { manager } \\
\text { and/or team }\end{array}$ & 3 & 3 & 1 & 1 & 1 & 3 & 1 & 1 & 1 & 1 & 1 \\
\hline
\end{tabular}

In the third TOPSIS step we must obtain the weight vector $\omega=\left(\omega_{1}, \omega_{2}, \ldots, \omega_{22}\right)$ for the twenty two criteria adopted. The weight vector defines the relative importance of the criteria in the opinion of the decision maker. For example, if we observe that $\omega_{1}<\omega_{2}$, we say that the criterion $C_{1}$ has less relative importance in the decision maker's opinion when compared to criteria $C_{2}$ or, in other words, the second criterion is more important than the first.

The process of determining the relative importance of the criteria can be done using different techniques according to Gomes and Lima (1992) and Gomes and Rangel(2009). In our numerical example, the twenty two chosen criteria were divided in eight groups, as defined in the second section of this paper and presented in Table 5 and Table 6. The possibility we suggest for determining the weights is to establish the relative amounts between the eight main groups of criteria (see Table 1), as shown in Table 6.

In order to determine relative weights of the eight groups of criteria (see Table 5), we used procedures of the Analytic Hierarchy Process methodology (SAATY, 1980; SAATY; PENIWATI, 2008) based on Saaty's scale and pairwise comparisons. In this approach, the 
decision maker must answer which is the most important criterion for all pairs (which, for the eight groups of criteria in Table 5, results in twenty eight comparisons). For example, in taking the first two groups in table 5 - Fund Manager and Team - the choice of decision makers was to consider the two groups as having the same relative importance, which resulted in equal weights of $25 \%$ for both groups. When comparing the sixth and seventh criteria groups in table 5 - Companies for investment and Governance -, decision makers considered the sixth group two times more important than the seventh, what ended up resulting in weights of $10 \%$ and $5 \%$, after normalization (so that $\omega_{1}+\omega_{2}+\cdots+\omega_{22}=100 \%$ ). Although it may seem laborious, the work of comparing criteria can be greatly facilitated by the use of computer software - such as the Expert Choice (2013), adopted for the numerical example presented in the article.

Before we consider the next steps of TOPSIS, it is worth remembering that although it is usual to weight vector normalized - that is, $\omega_{1}+\omega_{2}+\cdots+\omega_{22}=100 \%-$ such a procedure is not mandatory when using the TOPSIS method. In this article, we chose to normalize the weights.

Table 5 - Weights of Eight Criteria Groups

\begin{tabular}{l|c}
\hline \multicolumn{1}{c|}{ Criteria } & Weights \\
\hline Fund manager & $25 \%$ \\
\hline Team & $25 \%$ \\
\hline Investment Thesis & $10 \%$ \\
\hline Investment Process & $10 \%$ \\
\hline Financial aspects & $10 \%$ \\
\hline Business for Investments & $10 \%$ \\
\hline Governance & $5 \%$ \\
\hline History with the investor & $5 \%$ \\
\hline \multicolumn{1}{c|}{ Total } & $\mathbf{1 0 0 \%}$ \\
\hline
\end{tabular}

Table 6 - Weights of the Twenty Two Criteria

\begin{tabular}{c|c|c}
\hline & Criteria & Weights \\
\hline & Fund manager & $\mathbf{2 5 \%}$ \\
\hline 1 & Proven experience with PE & $4,17 \%$ \\
\hline 2 & Completed a cycle for a PE fund & $4,17 \%$ \\
\hline 3 & History of results & $4,17 \%$ \\
\hline 4 & Financial sustainability & $4,17 \%$ \\
\hline 5 & Financial commitment of the manager to the fund & $4,17 \%$ \\
\hline 6 & Relationship network & $4,17 \%$ \\
\hline & Team & $\mathbf{2 5 \%}$ \\
\hline
\end{tabular}




\begin{tabular}{|c|c|c|}
\hline 7 & Fund's Team Dedication & $4,17 \%$ \\
\hline 8 & Individual experience in PE & $4,17 \%$ \\
\hline 9 & Lenght of time working together & $4,17 \%$ \\
\hline 10 & Adherence of the team's profile focus to the fund & $4,17 \%$ \\
\hline 11 & Talent retention policy & $4,17 \%$ \\
\hline \multirow[t]{2}{*}{12} & Practitioners' turnover rate & $4,17 \%$ \\
\hline & Investment Thesis & $10 \%$ \\
\hline 13 & Investment strategy & $5,00 \%$ \\
\hline \multirow[t]{2}{*}{14} & Atractiveness & $5,00 \%$ \\
\hline & Investment Process & $10 \%$ \\
\hline 15 & Decision making process & $5,00 \%$ \\
\hline \multirow[t]{2}{*}{16} & Exit strategy & $5,00 \%$ \\
\hline & Financial aspects & $10 \%$ \\
\hline 17 & Structure of revenues and costs, and fees charged & $5,00 \%$ \\
\hline \multirow[t]{2}{*}{18} & Fund raising stage & $5,00 \%$ \\
\hline & Business for Investments & $10 \%$ \\
\hline 19 & Quality and alignment with th fund's focus & $5,00 \%$ \\
\hline \multirow[t]{2}{*}{20} & Stage of analysis and negotiation & $5,00 \%$ \\
\hline & Governance & $5 \%$ \\
\hline \multirow[t]{2}{*}{21} & Regulation & $5,00 \%$ \\
\hline & History with the Investor & $5 \%$ \\
\hline \multirow[t]{2}{*}{22} & $\begin{array}{l}\begin{array}{l}\text { Previous investments with the fund manager and/or } \\
\text { team }\end{array} \\
\end{array}$ & $5,00 \%$ \\
\hline & Total & $100 \%$ \\
\hline
\end{tabular}

The next three steps of TOPSIS lead to obtaining the normalized decision matrix, according to Table 7 . If we determine the general element in Table 4 as $a_{i j}$, where $i$ denotes the $\mathrm{i}$-th criterion $(1 \leq i \leq 22)$ and $j$ the $\mathrm{j}$-th PE fund $(1 \leq j \leq 11)$, then the generic element of the normalized decision matrix (denoted by $b_{i j}$ ) is given by

$$
b_{i j}=\frac{w_{i} a_{i j}}{\sqrt{\sum_{l=1} a_{i l}^{i}}} \forall 1 \leq i \leq 22 \text { and } 1 \leq j \leq 11
$$

where $\omega_{i}$ denotes the weight of the $i$-th criterion $(1 \leq i \leq 22)$, as shown in Table 6 . For example, we have that

$$
b_{11}=\frac{4,17 \% \times 5}{\sqrt{5^{2}+5^{2}+\ldots+2^{2}+5^{2}}} \approx 1.52 \%
$$

and

$$
b_{89}=\frac{4.17 \% \times 3}{\sqrt{3^{2}+3^{2}+\cdots+2^{2}+3^{2}}} \approx 1.21 \%
$$


Table 7 - Normalized Decision Matrix

\begin{tabular}{|c|c|c|c|c|c|c|c|c|c|c|c|c|}
\hline & Criteria & $\begin{array}{c}\text { Fund } \\
1\end{array}$ & \begin{tabular}{|c|} 
Fund \\
2
\end{tabular} & \begin{tabular}{|c|} 
Fund \\
3 \\
\end{tabular} & \begin{tabular}{|c|} 
Fund \\
4
\end{tabular} & $\begin{array}{c}\text { Fund } \\
5\end{array}$ & $\begin{array}{c}\text { Fund } \\
6\end{array}$ & $\begin{array}{c}\text { Fund } \\
7\end{array}$ & \begin{tabular}{|c|} 
Fund \\
8 \\
\end{tabular} & $\begin{array}{c}\text { Fund } \\
9\end{array}$ & $\begin{array}{c}\text { Fund } \\
10\end{array}$ & $\begin{array}{c}\text { Fund } \\
11\end{array}$ \\
\hline & Fund manager & & & & & & & & & & & \\
\hline 1 & $\begin{array}{c}\text { Proven experience } \\
\text { with PE } \\
\end{array}$ & $\begin{array}{c}1,52 \\
\%\end{array}$ & $1,52 \%$ & $1,52 \%$ & $1,52 \%$ & $0,91 \%$ & $1,52 \%$ & $0,30 \%$ & $1,21 \%$ & $0,91 \%$ & $0,61 \%$ & $1,52 \%$ \\
\hline 2 & $\begin{array}{l}\text { Completed a cycle } \\
\text { for a PE fund }\end{array}$ & $\begin{array}{c}0,99 \\
\%\end{array}$ & $0,99 \%$ & $2,47 \%$ & $1,98 \%$ & $0,49 \%$ & $0,49 \%$ & $0,49 \%$ & $0,49 \%$ & $0,49 \%$ & $0,49 \%$ & $1,98 \%$ \\
\hline 3 & History of results & $\begin{array}{c}1,77 \\
\%\end{array}$ & $1,77 \%$ & $1,77 \%$ & $1,77 \%$ & $0,35 \%$ & $1,06 \%$ & $0,35 \%$ & $0,35 \%$ & $0,35 \%$ & $0,35 \%$ & $1,77 \%$ \\
\hline 4 & $\begin{array}{c}\text { Financial } \\
\text { sustainability }\end{array}$ & $\begin{array}{c}1,38 \\
\%\end{array}$ & $1,38 \%$ & $1,38 \%$ & $1,38 \%$ & $1,38 \%$ & $1,38 \%$ & $0,28 \%$ & $1,38 \%$ & $1,38 \%$ & $0,28 \%$ & $1,38 \%$ \\
\hline 5 & $\begin{array}{l}\text { Financial } \\
\text { commitment of the } \\
\text { manager to the fund }\end{array}$ & $\begin{array}{c}0,81 \\
\%\end{array}$ & $2,03 \%$ & $1,63 \%$ & $2,03 \%$ & $0,41 \%$ & $0,81 \%$ & $1,22 \%$ & $0,81 \%$ & $1,22 \%$ & $0,81 \%$ & $0,81 \%$ \\
\hline \multirow[t]{2}{*}{6} & Relationship network & $\begin{array}{c}1,63 \\
\%\end{array}$ & $1,63 \%$ & $1,63 \%$ & $1,63 \%$ & $0,98 \%$ & $0,98 \%$ & $0,98 \%$ & $0,98 \%$ & $0,98 \%$ & $0,98 \%$ & $0,98 \%$ \\
\hline & Team & & & & & & & & & & & \\
\hline 7 & $\begin{array}{c}\text { Fund's Team } \\
\text { Dedication }\end{array}$ & $\begin{array}{c}0,91 \\
\%\end{array}$ & $0,91 \%$ & $1,36 \%$ & $1,36 \%$ & $0,45 \%$ & $2,27 \%$ & $1,36 \%$ & $0,91 \%$ & $1,36 \%$ & $1,36 \%$ & $0,45 \%$ \\
\hline 8 & \begin{tabular}{|c|} 
Individual experience \\
in $\mathrm{PE}$
\end{tabular} & $\begin{array}{c}1,21 \\
\%\end{array}$ & $1,21 \%$ & $1,61 \%$ & $1,21 \%$ & $1,21 \%$ & $2,01 \%$ & $0,81 \%$ & $0,81 \%$ & $1,21 \%$ & $0,81 \%$ & $1,21 \%$ \\
\hline 9 & $\begin{array}{c}\text { Lenght of time } \\
\text { working together }\end{array}$ & $\begin{array}{c}1,40 \\
\%\end{array}$ & $1,40 \%$ & $1,40 \%$ & $1,40 \%$ & $0,47 \%$ & $1,40 \%$ & $0,47 \%$ & $1,40 \%$ & $0,93 \%$ & $1,86 \%$ & $0,93 \%$ \\
\hline $\begin{array}{l}1 \\
0\end{array}$ & $\begin{array}{l}\text { Adherence of the } \\
\text { team's profile focus } \\
\text { to the fund } \\
\end{array}$ & $\begin{array}{c}1,21 \\
\%\end{array}$ & $0,81 \%$ & $1,61 \%$ & $1,21 \%$ & $0,81 \%$ & $1,61 \%$ & $0,81 \%$ & $0,81 \%$ & $1,21 \%$ & $1,61 \%$ & $1,61 \%$ \\
\hline $\begin{array}{l}1 \\
1 \\
\end{array}$ & $\begin{array}{c}\text { Talent retention } \\
\text { policy }\end{array}$ & $\begin{array}{c}1,21 \\
\%\end{array}$ & $1,21 \%$ & $2,01 \%$ & $1,21 \%$ & $0,40 \%$ & $1,21 \%$ & $0,40 \%$ & $0,40 \%$ & $1,21 \%$ & $1,21 \%$ & $2,01 \%$ \\
\hline $\begin{array}{l}1 \\
2 \\
\end{array}$ & $\begin{array}{l}\text { Practitioners' } \\
\text { turnover rate } \\
\end{array}$ & $\begin{array}{c}1,37 \\
\%\end{array}$ & $1,37 \%$ & $2,29 \%$ & $1,37 \%$ & $0,46 \%$ & $1,37 \%$ & $0,46 \%$ & $0,46 \%$ & $1,37 \%$ & $0,46 \%$ & $1,37 \%$ \\
\hline 2 & Investment Thesis & & & & & & & & & & & \\
\hline $\begin{array}{l}1 \\
3 \\
\end{array}$ & Investment strategy & $\begin{array}{c}1,35 \\
\%\end{array}$ & $1,35 \%$ & $1,35 \%$ & $1,35 \%$ & $1,35 \%$ & $2,25 \%$ & $2,25 \%$ & $1,35 \%$ & $1,35 \%$ & $0,45 \%$ & $1,35 \%$ \\
\hline \multirow[t]{2}{*}{$\begin{array}{l}1 \\
4 \\
\end{array}$} & Atractiveness & $\begin{array}{c}1,20 \\
\%\end{array}$ & $1,20 \%$ & $0,40 \%$ & $2,01 \%$ & $2,01 \%$ & $2,01 \%$ & $2,01 \%$ & $2,01 \%$ & $0,40 \%$ & $0,40 \%$ & $1,20 \%$ \\
\hline & Investment Process & & & & & & & & & & & \\
\hline $\begin{array}{l}1 \\
5 \\
\end{array}$ & $\begin{array}{c}\text { Decision making } \\
\text { process }\end{array}$ & $\begin{array}{c}2,25 \\
\%\end{array}$ & $2,25 \%$ & $1,35 \%$ & $1,35 \%$ & $0,45 \%$ & $1,35 \%$ & $1,35 \%$ & $0,45 \%$ & $1,35 \%$ & $0,45 \%$ & $2,25 \%$ \\
\hline \multirow[t]{2}{*}{$\begin{array}{l}1 \\
6 \\
\end{array}$} & Exit strategy & $\begin{array}{c}1,31 \\
\%\end{array}$ & $1,31 \%$ & $1,31 \%$ & $2,18 \%$ & $1,31 \%$ & $2,18 \%$ & $1,31 \%$ & $1,31 \%$ & $1,31 \%$ & $1,31 \%$ & $1,31 \%$ \\
\hline & Financial aspects & & & & & & & & & & & \\
\hline $\begin{array}{l}1 \\
7\end{array}$ & \begin{tabular}{|c|}
$\begin{array}{c}\text { Structure of revenues } \\
\text { and costs, and fees } \\
\text { charged }\end{array}$ \\
\end{tabular} & $\begin{array}{c}0,37 \\
\%\end{array}$ & $0,37 \%$ & $1,87 \%$ & $0,37 \%$ & $1,87 \%$ & $1,87 \%$ & $1,87 \%$ & $0,37 \%$ & $1,87 \%$ & $1,87 \%$ & $1,87 \%$ \\
\hline \multirow[t]{2}{*}{$\begin{array}{l}1 \\
8 \\
\end{array}$} & Fund raising stage & $\begin{array}{c}1,21 \\
\%\end{array}$ & $1,21 \%$ & $1,82 \%$ & $1,82 \%$ & $0,61 \%$ & $2,43 \%$ & $1,21 \%$ & $1,21 \%$ & $1,21 \%$ & $1,21 \%$ & $1,82 \%$ \\
\hline & $\begin{array}{l}\text { Business for } \\
\text { Investments }\end{array}$ & & & & & & & & & & & \\
\hline $\begin{array}{l}1 \\
9\end{array}$ & $\begin{array}{l}\text { Quality and } \\
\text { alignment with th } \\
\text { fund's focus }\end{array}$ & $\begin{array}{c}0,37 \\
\%\end{array}$ & $1,87 \%$ & $1,12 \%$ & $0,37 \%$ & $1,87 \%$ & $1,87 \%$ & $1,87 \%$ & $1,87 \%$ & $1,12 \%$ & $1,12 \%$ & $1,87 \%$ \\
\hline \multirow[t]{2}{*}{$\begin{array}{l}2 \\
0 \\
\end{array}$} & \begin{tabular}{|c|}
$\begin{array}{c}\text { Stage of analysis and } \\
\text { negotiation }\end{array}$ \\
\end{tabular} & $\begin{array}{c}1,03 \\
\% \\
\end{array}$ & $0,34 \%$ & $1,72 \%$ & $0,34 \%$ & $1,72 \%$ & $1,72 \%$ & $1,72 \%$ & $1,72 \%$ & $1,72 \%$ & $1,72 \%$ & $1,72 \%$ \\
\hline & Governance & & & & & & & & & & & \\
\hline \multirow[t]{2}{*}{$\begin{array}{l}2 \\
1 \\
\end{array}$} & Regulation & $\begin{array}{c}0,64 \\
\%\end{array}$ & $0,64 \%$ & $2,54 \%$ & $1,27 \%$ & $0,64 \%$ & $2,54 \%$ & $2,54 \%$ & $1,27 \%$ & $0,64 \%$ & $0,64 \%$ & $0,64 \%$ \\
\hline & $\begin{array}{c}\text { History with the } \\
\text { Investor }\end{array}$ & & & & & & & & & & & \\
\hline $\begin{array}{l}2 \\
2\end{array}$ & \begin{tabular}{|} 
Previous investments \\
with the fund \\
manager and/or team
\end{tabular} & $\begin{array}{c}2,54 \\
\%\end{array}$ & $2,54 \%$ & $0,85 \%$ & $0,85 \%$ & $0,85 \%$ & $2,54 \%$ & $0,85 \%$ & $0,85 \%$ & $0,85 \%$ & $0,85 \%$ & $0,85 \%$ \\
\hline
\end{tabular}


With the normalized decision matrix calculated, we can get the ideal solutions: one called positive (and denoted by $F^{+}=\left(f_{1}^{+} ; f_{2}^{+} ; \ldots ; f_{22}^{+}\right)$), the other called negative (and denoted $\left.F^{-}=\left(f_{1}^{-} ; f_{2}^{-} ; \ldots ; f_{22}^{-}\right)\right)$.

The mathematical definition of each element of the positive ideal solution is given by

$$
f_{i}^{+}=\operatorname{maximum}\left\{b_{i 1} ; b_{i 2} ; \ldots ; b_{i 11}\right\} \forall i=1,2, \ldots, 22
$$

while for each element of the negative optimal solution is given by

$$
f_{i}^{-}=\text {minhimum }\left\{b_{i 1} ; b_{i 2} ; \ldots ; b_{i 11}\right\} \forall i=1,2, \ldots, 22
$$

The ideal solutions (positive and negative) for our numerical example are presented in Table 8.

These two ideal solutions have interesting features:

1. The ideal positive solution $F^{+}$dominates all funds being considered. In other words, the ideal positive solution is to be preferred when compared to any of the funds considered, representing the best that could happen to the decision maker.

2. The ideal negative solution $F^{-}$is dominated by all funds being considered. In other words, the negative ideal solution should be disfavored when compared to any other fund being considered, representing the worst that could happen to the decision maker.

Table 8 - Ideals Solutions (Positive and Negative)

\begin{tabular}{c|c|c|c}
\hline & Criteria & Pos. Ideal Sol. & Neg. Ideal Sol. \\
\hline 1 & Fund manager & & \\
\hline 2 & Proven experience with PE & $1,52 \%$ & $0,30 \%$ \\
\hline 3 & Completed a cycle for a PE fund & $2,47 \%$ & $0,49 \%$ \\
\hline 4 & History of results & $1,77 \%$ & $0,35 \%$ \\
\hline 5 & Financial sustainability & $1,38 \%$ & $0,28 \%$ \\
\hline 6 & Relationship network & $2,03 \%$ & $0,41 \%$ \\
\hline & Team & $1,63 \%$ & $0,98 \%$ \\
\hline 7 & Fund's Team Dedication & & \\
\hline 8 & Individual experience in PE & $2,27 \%$ & $0,45 \%$ \\
\hline 9 & Lenght of time working together & $1,86 \%$ & $0,01 \%$ \\
\hline 10 & Adherence of the team's profile focus to the fund & $1,61 \%$ & $0,81 \%$ \\
\hline 11 & Talent retention policy & $2,01 \%$ & $0,40 \%$ \\
\hline 12 & Practitioners' turnover rate & $2,29 \%$ & $0,46 \%$ \\
\hline & Investment Thesis & & \\
\hline 13 & Investment strategy & $2,25 \%$ & $0,45 \%$ \\
\hline 14 & Atractiveness & $2,01 \%$ & $0,40 \%$ \\
\hline
\end{tabular}




\begin{tabular}{l|r|r|c}
\hline & Investment Process & \\
\hline 15 & Decision making process & $2,25 \%$ & $0,45 \%$ \\
\hline 16 & Exit strategy & $2,18 \%$ & $1,31 \%$ \\
\hline 17 & Financial aspects & \\
\hline 18 & Fund raising stage & $1,87 \%$ & $0,37 \%$ \\
\hline & Business for Investments & $2,43 \%$ & $0,61 \%$ \\
\hline 19 & Quality and alignment with th fund's focus & $1,87 \%$ & $0,37 \%$ \\
\hline 20 & Stage of analysis and negotiation & $1,72 \%$ & $0,34 \%$ \\
\hline & Governance & & \\
\hline 21 & Regulation & $2,54 \%$ & $0,64 \%$ \\
\hline 22 & Previous investments with the fund manager and/or team & $2,54 \%$ & $0,85 \%$ \\
\hline
\end{tabular}

According to the application of the TOPSIS method, the decision maker should prioritize funds that are close to the positive ideal solution and, at the same time, far from the negative ideal solution. In order to better understand the two ideal solutions in Table 8, it is interesting to compare these with the data of funds in Table 7. Let us take initially $F^{+}$and $F_{5}$ for comparison. We see that, according to the criterion $C_{1}$ the positive ideal solution dominates $F_{E}$ as $1.52 \%>0.91 \%$. We also see that in accordance with the criterion $C_{2}$, the positive ideal solution dominates fund $F_{5}$ as $2.47 \%>0.49 \%$. We can verify that the positive ideal solution will never be dominated by fund $F_{5}$ when compared with the other twenty criteria, one by one, which allows us to write that $F^{+}>F_{5}$. The same reasoning can be applied to ten other PE funds considered in the analysis, resulting in relative dominance relationships that can be defined as

$$
F^{+} \geqslant F_{i} \forall i=1,2, \ldots, 11
$$

Let us now compare directly $F^{-}$to the fund $F_{11}$. As we take the criterion $C_{1}$ for comparison, we observe that $1.52 \%>0.30 \%$, which implies that the negative solution is dominated by fund $F_{11}$ according to criterion $C_{1}$. We can repeat the comparison for criterion $C_{2}$ to obtain that $1.98 \%>0.49 \%$, which implies that the negative ideal solution is dominated by $F_{11}$. We can repeat the analysis to the other twenty criteria to establish that $F^{-}<F_{11}$. We can verify that the negative ideal solution is dominated by any one of the eleven PE funds considered for investment, which allows us to write in a generic way that

$$
F^{-} \vDash F_{i} \forall i=1,2, \ldots, 11
$$


On the eighth step of the TOPSIS method we must determine the distances of each PE fund to the positive ideal solution (denoted $\left.D^{+}=\left(d_{1}^{+} ; d_{2}^{+} ; \ldots ; d_{11}^{+}\right)\right)$and the negative ideal solution (denoted $\left.D^{-}=\left(d_{1}^{-} ; d_{2}^{-} ; \ldots ; d_{11}^{-}\right)\right)$. The calculation in this case is done as

$$
d_{j}^{+}=\sqrt{\sum_{l=1}^{22}\left(f_{l}^{+}-b_{l j}\right)^{2}} \forall j=1,2, \ldots, 11
$$

and

$$
d_{j}^{-}=\sqrt{\sum_{l=1}^{22}\left(f_{i}^{-}-b_{i j}\right)^{2}} \forall j=1,2, \ldots, 11
$$

The distances calculated for the numerical example are given in Table 9.

In the ninth step of the TOPSIS method requires defining the relative proximity for each PE fund as

$$
v_{j}=\frac{d_{j}}{d_{j}+d_{j}} \quad \forall j=1,2, \ldots, 11
$$

with the values obtained for the numerical example shown in Table 9. The higher the relative proximity measure of a fund, the closer will this fund be to the positive ideal solution and, at the same time, the furthest from the negative ideal solution. In other words, relative proximity directly provides the score for projects' ordination.

Tabela 9 - Distâncias,Relative Proximities and Final Ordering

\begin{tabular}{c|c|c|c|c|c|c|c|c|c|c|c} 
& \multicolumn{1}{c|}{$\begin{array}{c}\text { Fund } \\
\mathbf{1}\end{array}$} & $\begin{array}{c}\text { Fund } \\
\mathbf{2}\end{array}$ & $\begin{array}{c}\text { Fund } \\
\mathbf{3}\end{array}$ & $\begin{array}{c}\text { Fund } \\
\mathbf{4}\end{array}$ & $\begin{array}{c}\text { Fund } \\
\mathbf{5}\end{array}$ & $\begin{array}{c}\text { Fund } \\
\mathbf{6}\end{array}$ & $\begin{array}{c}\text { Fund } \\
\mathbf{7}\end{array}$ & $\begin{array}{c}\text { Fund } \\
\mathbf{8}\end{array}$ & $\begin{array}{c}\text { Fund } \\
\mathbf{9}\end{array}$ & $\begin{array}{c}\text { Fund } \\
\mathbf{1 0}\end{array}$ & $\begin{array}{c}\text { Fund } \\
\mathbf{1 1}\end{array}$ \\
\hline $\begin{array}{c}\text { Distance to Positive Ideal } \\
\text { Solution }\end{array}$ & $\begin{array}{c}4,53 \\
\%\end{array}$ & $\begin{array}{c}4,33 \\
\%\end{array}$ & $\begin{array}{c}3,28 \\
\%\end{array}$ & $\begin{array}{c}4,08 \\
\%\end{array}$ & $\begin{array}{c}6,04 \\
\%\end{array}$ & $\begin{array}{c}2,97 \\
\%\end{array}$ & $\begin{array}{c}5,14 \\
\%\end{array}$ & $\begin{array}{c}5,59 \\
\%\end{array}$ & $\begin{array}{c}4,98 \\
\%\end{array}$ & $5,88 \%$ & $4,11 \%$ \\
\hline $\begin{array}{c}\text { Distance to Negative Ideal } \\
\text { Solution }\end{array}$ & $\begin{array}{c}4,10 \\
\%\end{array}$ & $\begin{array}{c}4,57 \\
\%\end{array}$ & $\begin{array}{c}5,41 \\
\%\end{array}$ & $\begin{array}{c}4,51 \\
\%\end{array}$ & $\begin{array}{c}3,43 \\
\%\end{array}$ & $\begin{array}{c}5,91 \\
\%\end{array}$ & $\begin{array}{c}4,33 \\
\%\end{array}$ & $\begin{array}{c}3,40 \\
\%\end{array}$ & $\begin{array}{c}3,47 \\
\%\end{array}$ & $3,10 \%$ & $4,93 \%$ \\
\hline Relative Proximity & $\begin{array}{c}47,50 \\
\%\end{array}$ & $\begin{array}{c}51,37 \\
\%\end{array}$ & $\begin{array}{c}62,27 \\
\%\end{array}$ & $\begin{array}{c}52,50 \\
\%\end{array}$ & $\begin{array}{c}36,19 \\
\%\end{array}$ & $\begin{array}{c}66,52 \\
\%\end{array}$ & $\begin{array}{c}45,70 \\
\%\end{array}$ & $\begin{array}{c}37,84 \\
\%\end{array}$ & $\begin{array}{c}41,01 \\
\%\end{array}$ & $\begin{array}{c}34,54 \\
\%\end{array}$ & $\begin{array}{c}54,52 \\
\%\end{array}$ \\
\hline Order of Preference & $\mathbf{6}$ & $\mathbf{5}$ & $\mathbf{2}$ & $\mathbf{4}$ & $\mathbf{1 0}$ & $\mathbf{1}$ & $\mathbf{7}$ & $\mathbf{9}$ & $\mathbf{8}$ & $\mathbf{1 1}$ & $\mathbf{3}$ \\
\hline
\end{tabular}

Finally, in line with the values obtained in Table 9, in the tenth and final step of TOPSIS, we obtain the relative dominance of the eleven analyzed funds:

$$
F_{6}>F_{3}>F_{11}>F_{4}>F_{2}>F_{1}>F_{7}>F_{9}>F_{9}>F_{5}>F_{10}
$$

since $v_{6}>v_{3}>v_{11}>v_{4}>v_{2}>v_{1}>v_{7}>v_{9}>v_{3}>v_{5}>v_{10}$.

\section{SENSITIVITY ANALYSIS}

Once we have obtained the ordered result according to (11), at least two questions can be posed: 
1. How would this ordering be altered if other values for the relative importance of the criteria (given in Table 6) were tested? In other words, how would a sensitivity analysis of the weights impact the ordering given at (11)?

2. How would this ordering be altered if other values for the scores (given in Table 4) were tested? In other words, how would a sensitivity analysis of scores impact the ordering given at (11)?

As a first illustration, let us consider changing the relative importance of the criteria in line with Table 10. We see in this table that the weights of the first two groups of criteria (Managing Company and Team) are reduced (from 25\% to 15\%), while the weights of the next four groups of criteria (Investment Thesis, Investment Process, Financial Aspects and Companies for Investment) are increased (from 10\% to 15\%), with the last two criteria having their weight maintained. These alterations illustrate a change in the relative importance of the criteria directly related to the structure and history of the fund manager and its team (covered by the first two groups of criteria) when compared to the criteria directly related to its modus operandi, as thesis and investment process, financial aspects and possibilities of new investments in the market in interesting companies.

Table 10 - Sensitivity Analysis for the Relative Importance of the Criteria

\begin{tabular}{|c|c|c|c|}
\hline & Criteria & Initial Weights & Altered Weights \\
\hline & Fund manager & $25 \%$ & $15 \%$ \\
\hline 1 & Proven experience with PE & $4,17 \%$ & $2,50 \%$ \\
\hline 2 & Completed a cycle for a PE fund & $4,17 \%$ & $2,50 \%$ \\
\hline 3 & History of results & $4,17 \%$ & $2,50 \%$ \\
\hline 4 & Financial sustainability & $4,17 \%$ & $2,50 \%$ \\
\hline 5 & Financial commitment of the manager to the fund & $4,17 \%$ & $2,50 \%$ \\
\hline \multirow[t]{2}{*}{6} & Relationship network & $4,17 \%$ & $2,50 \%$ \\
\hline & Team & $25 \%$ & $15 \%$ \\
\hline 7 & Fund's Team Dedication & $4,17 \%$ & $2,50 \%$ \\
\hline 8 & Individual experience in $\mathbf{P E}$ & $4,17 \%$ & $2,50 \%$ \\
\hline 9 & Lenght of time working together & $4,17 \%$ & $2,50 \%$ \\
\hline 10 & Adherence of the team's profile focus to the fund & $4,17 \%$ & $2,50 \%$ \\
\hline 11 & Talent retention policy & $4,17 \%$ & $2,50 \%$ \\
\hline \multirow[t]{2}{*}{12} & Practitioners' turnover rate & $4,17 \%$ & $2,50 \%$ \\
\hline & Investment Thesis & $10 \%$ & $15 \%$ \\
\hline 13 & Investment strategy & $5,00 \%$ & $7,50 \%$ \\
\hline \multirow[t]{2}{*}{14} & Atractiveness & $5,00 \%$ & $7,50 \%$ \\
\hline & Investment Process & $10 \%$ & $15 \%$ \\
\hline 15 & Decision making process & $5,00 \%$ & $7,50 \%$ \\
\hline
\end{tabular}




\begin{tabular}{c|c|c|c}
\hline 16 & Exit strategy & $5,00 \%$ & $7,50 \%$ \\
\hline 17 & Financial aspects & $\mathbf{1 0 \%}$ & $\mathbf{1 5 \%}$ \\
\hline 18 & Structure of revenues and costs, and fees charged & $5,00 \%$ & $7,50 \%$ \\
\hline & Fund raising stage & $5,00 \%$ & $7,50 \%$ \\
\hline 19 & Qusiness for Investments & $\mathbf{1 0 \%}$ & $\mathbf{1 5 \%}$ \\
\hline 20 & Stage of analysis and negotiation & $5,00 \%$ & $7,50 \%$ \\
\hline & Governance & $5,00 \%$ & $7,50 \%$ \\
\hline 21 & Regulation & $\mathbf{5 \%}$ & $\mathbf{5 \%}$ \\
\hline & History with the Investor & $5,00 \%$ & $5,00 \%$ \\
\hline 22 & Previous investments with the fund manager and/or team & $5,00 \%$ & $\mathbf{5 \%}$ \\
\hline
\end{tabular}

The calculations can be performed for the changed weights in a similar manner to that shown in the previous section, finally resulting in the ordering

$$
F_{6}>F_{11}>F_{7}>F_{3}>F_{2}>F_{4}>F_{5}>F_{1}>F_{9}>F_{8}>F_{10}
$$

as the values shown in Table 11.

Table 11 - Distances, Relative Proximities and Final Ordering

\begin{tabular}{|c|c|c|c|c|c|c|c|c|c|c|c|}
\hline & $\begin{array}{c}\text { Fund } \\
1\end{array}$ & $\begin{array}{c}\text { Fund } \\
2\end{array}$ & $\begin{array}{c}\text { Fund } \\
3\end{array}$ & $\begin{array}{c}\text { Fund } \\
4\end{array}$ & $\begin{array}{c}\text { Fund } \\
5\end{array}$ & $\begin{array}{c}\text { Fund } \\
6\end{array}$ & $\begin{array}{c}\text { Fund } \\
7\end{array}$ & $\begin{array}{c}\text { Fund } \\
8\end{array}$ & $\begin{array}{c}\text { Fund } \\
9\end{array}$ & $\begin{array}{c}\text { Fund } \\
10\end{array}$ & $\begin{array}{c}\text { Fund } \\
11\end{array}$ \\
\hline $\begin{array}{r}\text { Distance to Positive Ideal } \\
\text { Solution }\end{array}$ & $\begin{array}{c}5,14 \\
\%\end{array}$ & $\begin{array}{c}4,93 \\
\%\end{array}$ & $\begin{array}{c}4,24 \\
\%\end{array}$ & $\begin{array}{c}5,01 \\
\%\end{array}$ & $\begin{array}{c}5,71 \\
\%\end{array}$ & $\begin{array}{c}2,17 \\
\%\end{array}$ & $\begin{array}{c}4,14 \\
\%\end{array}$ & $\begin{array}{c}5,54 \\
\%\end{array}$ & $\begin{array}{c}5,13 \\
\%\end{array}$ & $6,25 \%$ & $3,89 \%$ \\
\hline $\begin{array}{r}\text { Distance to Negative Ideal } \\
\text { Solution }\end{array}$ & $\begin{array}{c}4,29 \\
\%\end{array}$ & $\begin{array}{c}4,81 \\
\%\end{array}$ & $\begin{array}{c}4,95 \\
\%\end{array}$ & $\begin{array}{c}4,44 \\
\%\end{array}$ & $\begin{array}{c}4,80 \\
\%\end{array}$ & $\begin{array}{c}7,03 \\
\%\end{array}$ & $\begin{array}{c}5,90 \\
\%\end{array}$ & $\begin{array}{c}4,40 \\
\%\end{array}$ & $\begin{array}{c}4,17 \\
\%\end{array}$ & $3,66 \%$ & $5,73 \%$ \\
\hline Relative Proximity & $\begin{array}{c}45,46 \\
\%\end{array}$ & $\begin{array}{c}49,42 \\
\%\end{array}$ & $\begin{array}{c}53,85 \\
\%\end{array}$ & $\begin{array}{c}47,02 \\
\%\end{array}$ & $\begin{array}{c}45,67 \\
\%\end{array}$ & $\begin{array}{c}76,39 \\
\%\end{array}$ & $\begin{array}{c}58,77 \\
\%\end{array}$ & $\begin{array}{c}44,27 \\
\%\end{array}$ & $\begin{array}{c}44,82 \\
\%\end{array}$ & $\begin{array}{c}36,97 \\
\%\end{array}$ & $\begin{array}{c}59,58 \\
\%\end{array}$ \\
\hline Order of Preference & 8 & 5 & 4 & 6 & 7 & 1 & 3 & 10 & 9 & 11 & 2 \\
\hline
\end{tabular}

The comparison between orderings (11) and (12) (Table 9 and Table 11) shows that:

1. Funds such as $F_{6}, F_{11}$ and $F_{3}$ are among the top four in the two ordinances, this being an indication that must be seriously considered for investment.

2. Funds such as $F_{10}, F_{8}$ and $F_{9}$ are among the four worst in the two ordinances, this being an indication that they should not be considered for investment.

3. Funds such as $F_{2}, F_{4}$ and $F_{7}$ are in intermediate positions or among the top four, requiring a detailed research before being considered for investment.

4. Funds such as $F_{1}$ and $F_{5}$ are in intermediate positions or among the four worst, requiring a detailed investigation before being discarded permanently.

We can perform other sensitivity analyzes with other variations of the relative importance of the criteria. The main point when using a sensitivity analysis for a group of PE funds is to sort out those that are promising, that is, those that should be considered seriously for investment. 
In the second sensitivity analysis the scores presented in Table 4 were changed as shown in Table 12: the conversion scale was changed from $\mathrm{A}=5, \mathrm{~B}=4, \mathrm{C}=3, \mathrm{D}=2$ and $\mathrm{E}=1$, to $\mathrm{A}=8, \mathrm{~B}=6, \mathrm{C}=3, \mathrm{D}=2$ and $\mathrm{E}=1$. In this case, the importance of concepts " $\mathrm{A}$ " and " $\mathrm{B}$ " is enhanced when compared to the other three concepts. For illustration purposes, in this second sensitivity analysis, we reconsidered the relative importance of the criteria as in Table 5.

Table 12 - Sensitivity Analysis for the Funds Scores

\begin{tabular}{|c|c|c|c|c|c|c|c|c|c|c|c|c|}
\hline & Criteria & $\begin{array}{c}\text { Fund } \\
1 \\
\end{array}$ & $\begin{array}{c}\text { Fund } \\
2 \\
\end{array}$ & \begin{tabular}{|c|} 
Fund \\
$\mathbf{3}$ \\
\end{tabular} & $\begin{array}{c}\text { Fund } \\
4 \\
\end{array}$ & $\begin{array}{c}\text { Fund } \\
5 \\
\end{array}$ & $\begin{array}{c}\text { Fund } \\
6 \\
\end{array}$ & $\begin{array}{c}\text { Fund } \\
7 \\
\end{array}$ & $\begin{array}{c}\text { Fund } \\
8 \\
\end{array}$ & $\begin{array}{c}\text { Fund } \\
9 \\
\end{array}$ & \begin{tabular}{c|} 
Fund \\
10 \\
\end{tabular} & $\begin{array}{c}\text { Fund } \\
11 \\
\end{array}$ \\
\hline & Fund manager & & & & & & & & & & & \\
\hline 1 & Proven experience with PE & 8 & 8 & 8 & 8 & 3 & 8 & 1 & 6 & 3 & 2 & 8 \\
\hline 2 & Completed a cycle for a PE fund & 2 & 2 & 8 & 6 & 1 & 1 & 1 & 1 & 1 & 1 & 6 \\
\hline 3 & History of results & 8 & 8 & 8 & 8 & 1 & 3 & 1 & 1 & 1 & 1 & 8 \\
\hline 4 & Financial sustainability & 8 & 8 & 8 & 8 & 8 & 8 & 1 & 8 & 8 & 1 & 8 \\
\hline 5 & $\begin{array}{l}\text { Financial commitment of the } \\
\text { manager to the fund }\end{array}$ & 2 & 8 & 6 & 8 & 1 & 2 & 3 & 2 & 3 & 2 & 2 \\
\hline \multirow[t]{2}{*}{6} & Relationship network & 8 & 8 & 8 & 8 & 3 & 3 & 3 & 3 & 3 & 3 & 3 \\
\hline & Team & & & & & & & & & & & \\
\hline 7 & Fund's Team Dedication & 2 & 2 & 3 & 3 & 1 & 8 & 3 & 2 & 3 & 3 & 1 \\
\hline 8 & Individual experience in PE & 3 & 3 & 6 & 3 & 3 & 8 & 2 & 2 & 3 & 2 & 3 \\
\hline 9 & Lenght of time working together & 3 & 3 & 3 & 3 & 1 & 3 & 1 & 3 & 2 & 6 & 2 \\
\hline 10 & $\begin{array}{l}\text { Adherence of the team's profile } \\
\text { focus to the fund }\end{array}$ & 3 & 2 & 6 & 3 & 2 & 6 & 2 & 2 & 3 & 6 & 6 \\
\hline 11 & Talent retention policy & 3 & 3 & 8 & 3 & 1 & 3 & 1 & 1 & 3 & 3 & 8 \\
\hline \multirow[t]{2}{*}{12} & Practitioners' turnover rate & 3 & 3 & 8 & 3 & 1 & 3 & 1 & 1 & 3 & 1 & 3 \\
\hline & Investment Thesis & & & & & & & & & & & \\
\hline 13 & Investment strategy & 3 & 3 & 3 & 3 & 3 & 8 & 8 & 3 & 3 & 1 & 3 \\
\hline \multirow[t]{2}{*}{14} & Atractiveness & 3 & 3 & 1 & 8 & 8 & 8 & 8 & 8 & 1 & 1 & 3 \\
\hline & Investment Process & & & & & & & & & & & \\
\hline 15 & Decision making process & 8 & 8 & 3 & 3 & 1 & 3 & 3 & 1 & 3 & 1 & 8 \\
\hline \multirow[t]{2}{*}{16} & Exit strategy & 3 & 3 & 3 & 8 & 3 & 8 & 3 & 3 & 3 & 3 & 3 \\
\hline & Financial aspects & & & & & & & & & & & \\
\hline 17 & $\begin{array}{c}\text { Structure of revenues and costs, } \\
\text { and fees charged }\end{array}$ & 1 & 1 & 8 & 1 & 8 & 8 & 8 & 1 & 8 & 8 & 8 \\
\hline \multirow[t]{2}{*}{18} & Fund raising stage & 2 & 2 & 3 & 3 & 1 & 6 & 2 & 2 & 2 & 2 & 3 \\
\hline & Business for Investments & & & & & & & & & & & \\
\hline 19 & $\begin{array}{l}\text { Quality and alignment with th } \\
\text { fund's focus }\end{array}$ & 1 & 8 & 3 & 1 & 8 & 8 & 8 & 8 & 3 & 3 & 8 \\
\hline \multirow[t]{2}{*}{20} & Stage of analysis and negotiation & 3 & 1 & 8 & 1 & 8 & 8 & 8 & 8 & 8 & 8 & 8 \\
\hline & Governance & & & & & & & & & & & \\
\hline \multirow[t]{2}{*}{21} & Regulation & 1 & 1 & 6 & 2 & 1 & 6 & 6 & 2 & 1 & 1 & 1 \\
\hline & History with the Investor & & & & & & & & & & & \\
\hline 22 & $\begin{array}{l}\text { Previous investments with the } \\
\text { fund manager and/or team }\end{array}$ & 3 & 3 & 1 & 1 & 1 & 3 & 1 & 1 & 1 & 1 & 1 \\
\hline
\end{tabular}

With the scores given in Table 12, after the calculations according to the previous section, we obtain the following ordering 


$$
F_{6}>F_{3}>F_{11}>F_{4}>F_{2}>F_{7}>F_{1}>F_{8}>F_{5}>F_{10}>F_{9}
$$

in line with the results shown in Table 13.

Table 13 - Distances, Relative Proximities and Final Ordering

\begin{tabular}{|c|c|c|c|c|c|c|c|c|c|c|c|}
\hline & $\begin{array}{c}\text { Fund } \\
1\end{array}$ & $\begin{array}{c}\text { Fund } \\
2\end{array}$ & $\begin{array}{c}\text { Fund } \\
3\end{array}$ & $\begin{array}{c}\text { Fund } \\
4\end{array}$ & $\begin{array}{c}\text { Fund } \\
5\end{array}$ & $\begin{array}{c}\text { Fund } \\
6\end{array}$ & $\begin{array}{c}\text { Fund } \\
7\end{array}$ & $\begin{array}{c}\text { Fund } \\
8\end{array}$ & $\begin{array}{c}\text { Fund } \\
9\end{array}$ & $\begin{array}{c}\text { Fund } \\
10\end{array}$ & $\begin{array}{c}\text { Fund } \\
11\end{array}$ \\
\hline $\begin{array}{r}\text { Distance } 1 \\
\mathrm{~S}\end{array}$ & $\begin{array}{c}6,93 \\
\%\end{array}$ & $\begin{array}{c}6,62 \\
\% \\
\end{array}$ & $\begin{array}{c}5,15 \\
\%\end{array}$ & $\begin{array}{c}6,14 \\
\%\end{array}$ & $\begin{array}{c}8,24 \\
\%\end{array}$ & $\begin{array}{c}4,63 \\
\% \\
\end{array}$ & $\begin{array}{c}7,27 \\
\% \\
\end{array}$ & $\begin{array}{c}7,83 \\
\%\end{array}$ & $\begin{array}{c}7,39 \\
\% \\
\end{array}$ & $99 \%$ & $\%$ \\
\hline $\begin{array}{r}\text { Distance to } \\
\text { So }\end{array}$ & $\begin{array}{c}4,32 \\
\%\end{array}$ & $\begin{array}{c}5,05 \\
\%\end{array}$ & $\begin{array}{c}6,41 \\
\%\end{array}$ & $\begin{array}{c}5,05 \\
\%\end{array}$ & $\begin{array}{c}3,76 \\
\%\end{array}$ & $\begin{array}{c}7,35 \\
\%\end{array}$ & $\begin{array}{c}4,97 \\
\%\end{array}$ & $\begin{array}{c}3,63 \\
\%\end{array}$ & $\begin{array}{c}3,27 \\
\%\end{array}$ &, $58 \%$ & ,59\% \\
\hline Relative Proximity & $\begin{array}{c}38,42 \\
\%\end{array}$ & $\begin{array}{c}43,27 \\
\%\end{array}$ & $\begin{array}{c}55,44 \\
\%\end{array}$ & $\begin{array}{c}45,14 \\
\%\end{array}$ & $\begin{array}{c}31,31 \\
\%\end{array}$ & $\begin{array}{c}61,32 \\
\%\end{array}$ & $\begin{array}{c}40,63 \\
\% \\
\end{array}$ & $\begin{array}{c}31,68 \\
\%\end{array}$ & $\begin{array}{c}30,70 \\
\%\end{array}$ & $\begin{array}{c}30,96 \\
\%\end{array}$ & $\begin{array}{c}47,18 \\
\%\end{array}$ \\
\hline Order of Preference & 7 & 5 & 2 & 4 & 9 & 1 & 6 & 8 & 11 & 10 & 3 \\
\hline
\end{tabular}

Comparing the orderings (11) and (13) shows that:

1. The four funds ordered as the best did not change. The results reinforce the conclusion that these are the best investment alternatives

2. The four funds ordered as the worst are still the same, which reinforces the perception that they should not be considered for investment.

3. Finally, although the three funds in the intermediate positions are still the same, there has been a change in the relative positions of two of them. In the light of all the results presented, these three funds can still be considered for investment as long as they undergo further analyses.

\section{CONCLUSION}

In this article we presented a methodology for selection of PE funds in Brazil. The methodology was based on multi-criteria decision analysis. Twenty two criteria were used, covering aspects related to management structure, human resources, investment thesis, investment process, financial aspects, companies for investment, governance and history. The criteria chosen were comprehensive and can be easily analyzed and qualified when conducting a due diligence on any PE fund.

The analysis considered eleven PE funds available in the Brazilian market at the end of 2013. The multicriteria method adopted in this study for numerical illustration was TOPSIS. The numerical results were presented and explained, as well as two examples of the use of the sensitivity analysis to investigate the impacts of small changes in the entry parameters. 
The methodology can greatly facilitate the ranking of PE funds under consideration for investment, significantly simplifying the decision-making process in the investment committee of any institution.

The PE market in Brazil is expanding, so the number of funds available for investment should grow. Faced with a large number of investment funds, the use of the proposed methodology is even more appropriate, given that there is no limitation on the number of funds considered during the analysis.

In terms of future developments, extensions from the point of view of multicriteria analysis are possible, with the possible use of other multicriteria methods. For example, the application of the sensitivity analysis helps understanding of the impact of small changes in the data on the final ranking, but the reader can also consider other possibilities, such fuzzy methods or Monte Carlo simulation techniques.

A second point for future development is related to the inclusion/modification of the set of criteria, in the case of new opportunities in PE investment arise. For example, a specific situation in which there may be an increase in the total number of criteria is related to the investments being considered by Brazilian pension funds in PE outside Brazil, something that does not occur yet today. Let us remember that investments in other currencies (other than BRL) lead to currency risk due to unanticipated fluctuations in exchange rates, which demands attention from investors in order to control potential foreign exchange losses. A second example is related to the sovereign risk because, by performing investments abroad, the sums which have been sent outside Brazil shall be subject to another country internal problems (e.g., political), that can lead in extreme situations to expropriation of the investments. Therefore, the inclusion of criteria that addresses exchange rate and sovereign risks when overseas investment are considered become imperative. It is important to mention that the inclusion of more criteria does not impose restrictions on the use of multicriteria analysis, although it may demand more work by the analysts responsible for the due diligence of each fund being considered when establishing scores.

\section{CONTRIBUTIONS OF AUTHORS}

The article is the result of Luiz dissertation, under my guidance. The final wording of the article was mine, based on the numerical results obtained by Luiz (by me requests for guidance), as well as other results we obtained after the defense of the dissertation. 


\section{REFERENCES}

ABDI. Agência Brasileira de Desenvolvimento Industrial. A indústria de private equity e venture capital: segundo censo brasileiro. Relatório Técnico de Pesquisa, ABDI, Brasília, 2011.

BANA E COSTA, C. A.; SOARES, J. O. A multicriteria model for portfolio management. The European Journal of Finance, v. 10, n. 3, p. 198-211, 2010.

BYGRAVE, W.; TIMMONS, J. Venture capital at the crossroads. Boston: Harvard Business School Press, 1992.

CFA INSTITUTE. Corporate finance and portfolio management. Boston: Pearson Custom Publishing, 2009.

CHEN, P.; BAIERL, G.; KAPLAN, P. Venture capital and its role in strategic asset allocation. Journal of Portfolio Management, v. 28, n. 3, p. 83-90, 2002.

CLEMEN, R. T.; REILLY, T. Making hard decisions with decision tools. Duxbury: Thomson Learning, 2001.

COCHRANE, J. The risk and return of venture capital. Journal of Financial Economics, v. 75, n. 1 , p. 3-52, 2005.

CVM. Comissão de Valores Mobiliários. Instrução 391. Disponível em: $\langle$ http://www.cvm.gov.br/asp/cvmwww/atos/Atos_Redir.asp?File=linstlinst391consolid.doc〉. Acesso em: 23 nov. 2014.

DAMODARAN, A. Investment valuation: tools and techniques for determining the value of any asset. Hoboken: Wiley, 2012.

DE ZWART, G.; FRIESER, B.; VAN DIJK, D. Private equity recommitment strategies for institutional investors. Financial Analysts Journal, v. 68, n. 2, p. 81-99, 2012.

DOUMPOS, M.; ZOPOUNIDIS, C. A multicriteria decision support system for bank rating. Decision Support Systems, v. 50, n. 2, p. 55-63, 2010.

;___ A multicriteria outranking modeling approach for credit rating. Decision Sciences, v. 42, n. 4, p. 721-742, 2011.

DUARTE JUNIOR, A. M.; LISBOA, J. L. G. Seleção de debêntures no mercado de renda fixa brasileiro. Revista de Finanças Aplicadas, v. 1, n. 1, p. 1-22, 2013.

EHRGOTT, M.; FIGUEIRA, J. R.; GRECCO, S. (Eds.). Trends in multiple criteria decision analysis. Berlin: Springer, 2010.

EXPERT CHOICE. Manual do usuário. Arlington: Expert Choice, 2013.

FABOZZI, F.J. Fixed income securities. New York: McGraw-Hill, 2012.

FRASER-SAMPSON, G. Private equity as an asset class. Hoboken: Wiley, 2010. 
GOMES, L. F. A. M.; LIMA, M. M. P. P. TODIM: basics and application to multicriteria ranking of projects with environmental impacts. Foundations of Computing and Decision Sciences, v. 16, n. 2, p. 113-127, 1992.

GOMES, L. F. A. M.; ARAYA, M. C. G.; CARIGNANO, C. Tomada de decisões em cenários complexos. Rio de Janeiro: Pioneira Thomson Learning, 2004.

GOMES, L. F. A. M.; RANGEL, L. A. D. An application of the TODIM method to multicriteria rental evaluation of residential properties. Journal of Operational Research, v. 193, n. 2, p. 204-211, 2009.

GOMPERS, P.; LERNER, J. Risk and reward in private equity investments: the challengeof performance assessment. Journal of Private Equity, v. 1, n. 1, p. 5-12, 1997.

.;___. An analysis of competition in the U.S. venture capital partnership. Journal of Financial Economics, v. 51, n. 1, p. 3-44, 1999.

.; __ The venture capital cycle. Cambridge: MIT Press, 2004.

HALLERBACH, W. G.; SPRONK, J. The relevance of MCDM for financial decisions. Journal of Multi-Criteria Decision Analysis, v. 11, n. 2, p. 187-195, 2002.

HAN, S. H. et al. Multicriteria financial portfolio risk management for international projects. Journal of Construction Engineering and Management, v. 130, n. 3, p. 346-356, 2004.

HWANG, C. L.; YOON, K. P. Multiple attribute decision making: methods and applications. New York: Springer-Verlag, 1981.

KAPLAN, S.; SCHOAR, A. Private equity performance: returns, persistence, and capital flows. Journal of Finance, v. 60, n. 3, p. 1791-1823, 2005.

KAPLAN, S.; STROMBERG, P. Leverage buyouts and private equity. Journal of Economic Perspectives, v. 23, n. 1, p. 121-46, 2009.

KPMG. Consolidação de dados da indústria de private equity e venture capital no Brasil. 2013. Disponível em: 〈http://www.abvcap.com.br/pesquisas/estudos.aspx>. Acesso em: 15 jan. 2014.

LERNER, J.; FELDA, H.; LEAMON, A. Venture capital and private equity: a casebook. Hoboken: Wiley, 2012.

LOPES, A. B.; FURTADO, C. V. Private equity na carteira de investimentos das entidades de previdência privada. Revista Contabilidade \& Finanças, v. 5, n. 2, p. 108-126, 2006.

MAGINN, J. L. et al. Managing investment portfolios: a dynamic process. Newark: CFA Institute Investment Series, 2009.

MATSATSINIS, N. F.; DOUMPOS, M.; ZOPOUNIDIS, C. Knowledge acquisition and representation for expert systems in the field of financial analysis. Expert Systems With Applications, v. 12, n. 2, p. 247-262, 1997. 
METRICK, A.; YASUDA, A. The economics of private equity funds. Review of Financial Studies, v. 23, n. 4, p. 2303-2341, 2010.

PHALIPPOU, L. Beware when venturing into private equity. Journal of Economic Perspectives, v. 23, n. 1, p. 147-166, 2009.

PHALIPPOU, L.; GOTTSCHALG, O. The performance of private equity funds. Review of Financial Studies, v. 22, n. 3, p. 1747-1776, 2009.

SAATY, T. L. The analytic hierarchy process. New York: McGraw Hill, 1980.

SAATY, T. L.; PENIWATI, K. Group decision making: drawing out and reconciling differences. Pittsburgh: RWS Publications, 2008.

SAHAJWALA, R.; VAN DEN BERGH, P. Supervisory risk assessment and early warning systems. Technical Report, Bank of International Settlements, Basel, 2000.

SANT'ANNA, A. P.; NOGUEIRA, H. D.; RABEL, L. M. Comparação entre métodos multicritério em um modelo para avaliação da qualidade de ativos de renda variável. Revista de Finanças Aplicadas, v. 1, n. 1, p. 1-21, 2011.

STEUER, R. E.; NA, P. Multiple criteria decision making combined with finance: a categorized bibliographic study. European Journal of Operational Research, v. 150, n. 3, p. 496-515, 2003.

STEUER, R. E.; QI, Y.; HIRSCHBERGER, M. Suitable-portfolio investors, nondominated frontier sensitivity, and the effect of multiple objectives on standard portfolio selection. Annals of Operations Research, v. 152, n. 3, p. 297-317, 2007.

STOWE, J. D. et al. Equity asset valuation. Hoboken: Wiley, 2007.

SWENSEN, D. F. Pioneering portfolio management: an unconventional approach toinstitutional investment. New York: Free Press, 2009.

TUCKMAN, B.; SERRAT, A. Fixed income securities. Hoboken: Wiley, 2011.

XIDONAS, P. et al. IPSSIS: an integrated multicriteria decision support system for equity portfolio construction and selection. European Journal of Operational Research, v. 210, n. 2, p. 398-409, 2011.

XIDONAS, P. et al. Multicriteria portfolio management. New York: Springer, 2012.

ZAVADSKAS, E. K.; TURSKIS, Z. Multiple criteria decision making methods in economics: an overview. Technological and Economic Development of Economy, v. 17, n. 2, p. 397 427, 2011.

ZOPOUNIDIS, C.; DOUMPOS, M. Developing a multicriteria decision support system for financial classification problems: The FINCLAS system. Optimization Methods and Software, v. 8, n. 2, p. 277-304, 1998.

ZOPOUNIDIS, C. Multicriteria decision aid in financial management. European Journal of Operational Research, v. 119, n. 3, p. 404-415, 1999. 
ZOPOUNIDIS, C.; DOUMPOS, M.; ZANAKIS, S. H. Stock evaluation using a preference disaggregation methodology. Decision Sciences, v. 30, n. 2, p. 313-336, 1999.

YOON, K. P. A reconciliation among discrete compromise situations. Journal of Operational Research Society, v. 38, n. 2, p. 277-286, 1987.

YOON, K. P.; HWANG, C. Multiple attribute decision making: an introduction. San Francisco: SAGE publications, 1995.

WALLENIUS, J. et al. Multiple criteria decision making, multiattribute utility function: recent accomplishments and what lies ahead. Management Science, v. 54, n. 4, p. 13361349, 2008.

\section{ATTACHMENT - TOPSIS METHOD USED IN THE ARTICLE}

Step 1: Define $n$ criteria, denoted by $C_{1}, C_{2}, \ldots, C_{\mathrm{n}}$.

Step 2: Define $m$ alternatives (i.e., PE funds) for analysis and ordering, denoted by $F_{1}$, $F_{2}, \ldots, F m$.

Step 3: Obtain the weight vector (or relative importance) for the criteria adopted,

denoted $\omega=\left(\omega_{1}, \omega_{2}, \ldots, \omega_{n}\right)$, such that $\omega_{1}+\omega_{2}+\cdots+\omega_{n}=100 \%$.

Step 4: Establish the scores for each alternative, according to each criterion, resulting in a table with $n \times m$ scores.

Step 5: Obtain a numerical evaluation matrix whose general element is denoted by $a_{\mathrm{ij}}$,

where $i$ represents the $\mathrm{i}$-th criterion $(1 \leq i \leq n)$ and $j$ the $\mathrm{j}$-th alternative $(1 \leq j \leq n)$.

Step 6: Obtain the standard decision matrix whose generic element $b_{i j}$ is calculated as

$$
b_{i j}=\frac{\omega_{i} \times a_{i j}}{\sqrt{\sum_{l=1}^{m} a_{i l}^{n}}} \forall 1 \leq i \leq n \text { and } 1 \leq j \leq m
$$

Step 7: Obtain the positive ideal solution, denoted by ${F^{+}}^{+}=\left(f_{1}^{+} ; f_{2}^{+} ; \ldots ; f_{n}^{+}\right)$, and the positive ideal solution, denoted by $F^{-}=\left(f_{1}^{-} ; f_{2}^{-} ; \ldots ; f_{n}^{-}\right)$. The mathematical definition of each element of the positive ideal solution is given by

$$
f_{i}^{+}=\operatorname{maximum}\left\{b_{i 1}, b_{i 2} ; \ldots ; b_{i m}\right\} \forall i=1,2, \ldots, n
$$


while for each element of the negative ideal solution is given by

$$
f_{i}^{-}=\operatorname{minimum}\left\{b_{i 1} ; b_{i 2} ; \ldots ; b_{i m}\right\} \forall i=1,2, \ldots, n
$$

Step 8: Obtain the distances of each of the alternatives for the positive ideal solution (denoted $D^{+}=\left(d_{1}^{+} ; d_{2}^{+} ; \ldots ; d_{m}^{+}\right)$) and for the negative ideal solution (denoted $\left.D^{-}=\left(d_{1}^{-} ; d_{2}^{-} ; \ldots ; d_{m}^{-}\right)\right)$. The calculation in this case is made as

$$
d_{j}^{+}=\sqrt{\sum_{l=1}^{\mathrm{n}}\left(f_{l}^{+}-b_{l j}\right)^{2}} \forall j=1,2, \ldots, m
$$

and for the negative ideal solution as

$$
d_{j}^{-}=\sqrt{\sum_{l=1}^{n}\left(f_{l}^{-}-b_{l j}\right)^{2}} \forall j=1,2, \ldots, m
$$

Step 9: Obtain the relative proximities on for each alternative as

$$
v_{j}=\frac{d_{j}}{d \dagger+d_{j}} \quad \forall j=1,2, \ldots, m
$$

Step 10: Order of the $m$ alternatives that must satisfy

$$
F_{k} \geqslant F_{l} \Leftrightarrow v_{k} \geq v_{l} \forall k, l=1,2, \ldots, m
$$

